\title{
Geology of a Neogene caldera cluster in Northeast Iceland - clues into rift zone architecture on a young Iceland
}

Steffi Burchardt ${ }^{1,2^{*}}$, Birgir V. Óskarsson ${ }^{3}$, Ludvik E. Gustafsson ${ }^{4}$, Sylvia E. Berg ${ }^{1,5}$, Morten S. Riishuus ${ }^{6}$

51 Department of Earth Sciences, Uppsala University, Uppsala, Sweden

52 Center for Natural Hazard and Disaster Science (CNDS), Sweden

3 Icelandic Institute of Natural History

4 Retired. Ludvik.e.gustafsson@gmail.com

5 Thyréns, Stockholm, Sweden

6 Faroese Geological Survey, Tórshavn, Faroe Islands

$10 *$ steffi.burchardt@geo.uu.se

Twitter: @inthevolcano

This is a non-peer reviewed manuscript submitted to Volcanica. 


\section{ABSTRACT}

The Borgarfjörður-Loðmundarfjörður area in Northeast Iceland hosts an unusual volume of silicic rocks, as well as volcanic and sub-volcanic structures emplaced in the Miocene between 13.5 and 12.2 Ma. Here, we summarise the geology of the

5 area and present a new geological map to summarise the current state of knowledge. We describe the prominent features of the volcanic centres, as well as regional marker horizons. Notably, the volume of silicic rocks, the distribution of eruptive centres, calderas, and intrusion swarms, as well as the interplay between regional flood basalts and silicic magmatism indicate a rift zone architecture different to that of the present day.

10 ÁGRIP

Í Borgarfirði eystri og Loðmundarfirði er óvenjulega mikið af súrum bergtegundum, t.d. hraunum, innskotsbergi, flikrubergi og gjóskulögum sem urðu til á Míósentímabilinu milli 13.5 til 12.2 má. Súra bergið má rekja til nokkurra eldstöðva sem pegar hafa verið rannsakaðar, en einnig finnast leifar eldstöðva sem eftir er að skoða nánar. Greint verður frá rannsóknunum sem pegar hafa átt sér stað. Flestar eldstöðvar hafa myndað öskjur í gríðarlegum sprengigosum. Gosin virðast hafa átt sér

15 stað nær samtímis og í peim urðu til umfangsmikil flikrubergslög sem jafnvel eru pau mestu á Íslandi. Frekari rannsókna er pörf til að setja myndun pessa svæðis í samhengi við jarðfræðilega myndun Austurlands og til að finna ástæðu fyrir hinum óvenju umfangsmiklu sprengigosum. Í pví skyni eru lagðar til ákveðnar rannsóknir til að nálgast heildarmyndina.

\section{INTRODUCTION}

20 The interaction between the mantle anomaly beneath Iceland (Iceland plume) and spreading at the Mid-Atlantic ridge (MAR) has produced a variety of tectono-magmatic phenomena, among them the Iceland plateau with an anomalously thick crust, magmatic and tectonic activity in rift zones and flank zones with distinct characters (Saemundsson, 1979; Sigmundsson, 2006), as well as the generation of silicic rocks in amounts unusual for a mid-ocean ridge setting (Berg et al., 2014; Sigmarsson et al., 2008; Walker, 1965). Iceland has therefore been discussed to be an analogue for the

25 formation of continental crust on an early Earth (Berg et al., 2014a). However, the temporal evolution of its rift-zone tectonics and magmatism during the earliest phase of formation is still unclear. More specifically, while conceptual models of rift zone relocation due to movement of the plate boundary relative to the Iceland Plume theoretically explain the distribution of magmatic and tectonic activity in the past, confusion still exists about rift zone configuration, especially in the region of the Jan Mayen microcontinent after the Kolbeinsey Ridge had taken over

30 from the Ægir Ridge as the active rift zone in NE Atlantic (Fig. 1; Blischke, 2020; Foulger et al., 2021; Hjartason et al., 2017). Moreover, when discussing the tectono-magmatic evolution of the North Atlantic and early Iceland in the geological past, we generally apply concepts based on observations of the current rift zone. 
The extinct volcanoes of Eastern Iceland have been the subject of investigations on the architecture of rift zones, as they represent fossil evidence of the tectono-magmatic evolution of Iceland through time (Gibson, 1963; Helgason, 1984; Palmason, 1980; Walker, 1975). However, the central volcanoes of the area between Héraðsflói and Seyðisfjörður have received comparatively little attention, despite the wealth of geological phenomena (Berg et al.,

5 2014b). The area that comprises the inhabited fjord of Borgarfjörður eystri, the adjacent deserted coastal inlets, and the uninhabited fjord Loðmundarfjörður hosts a cluster of Neogene volcanoes that experienced a phase of violent explosive eruptions between about 13.5 and 12.2 Ma (Fig. 2) (Berg, 2016; Burchardt et al., 2011; Gustafsson et al., 1989). Several collapse calderas, sub-volcanic intrusions, and large amounts of effusive silicic rocks are preceded by, and intercalated with, voluminous flood basalts. These basalts have been suggested to reflect a more pronounced and

10 wider-spread activity of the Iceland plume (Óskarsson \& Riishuus, 2013, 2014).

Here we summarise what is currently known about the geology of the Borgarfjörður eystri-Loðmundarfjörður (BEL) area, including the regional geological context and detailed maps that focus on the intermediate and silicic rocks, as well as marker horizons, and descriptions of key geological features. Our study area provides a unique window into the tectono-magmatic activity during the Neogene. And while much is still unknown about this little studied area, many

15 lines of evidence suggest that the Neogene rift zone of Iceland may have been unlike the current rift zone. Hence, we may need to reconsider the application of the current concept of a rift zone in the geological past.

\section{GEOLOGICAL SETTING}

Iceland is the surface expression of the Iceland mantle plume superimposed on the MAR. The Iceland plume is a

20 stationary mantle anomaly that impinged below Laurentia (current Greenland) in the Late Cretaceous and produced a Large Igneous Province, called the North Atlantic Igneous Province (NAIP). NAIP magmatism associated with continental break-up occurred in Greenland, the British Isles, and the Faeroe-Shetland basin in the Early Palaeogene (Saunders et al., 1997). Due to the slight westward drift of the MAR relative to the Iceland plume, the plate boundary (MAR) episodically "jumps" to the east and re-establishes in as a new rift zone (Fig. 1a; Helgason, 1984). In this way,

25 the currently active Kolbeinsey Ridge took over from the Ægir Ridge as the main active rift zone in the North Atlantic around $30 \mathrm{Ma}$. At the same time, the Iceland plume may have started to influence lava production on the rift segment that later became Iceland, thus creating an anomalously thick crust and elevating segments of the MAR above sea level (Steinberger et al., 2019; Torsvik et al., 2001, 2015).

At present Iceland hosts three main segments of the MAR, the western, eastern and northern volcanic zones, and two

30 off-rift zones, the Snæfellsnes (SFZ) and the Öræfajökull (ÖFZ) flank zone (Fig. 1b; e.g. Sigmundsson, 2006). Two transform zones occur between the volcanic zones, the South Iceland Seismic Zone (SISZ) that links the West Volcanic Zone (WVZ) and the East Volcanic Zone (EVZ), and the Tjörnes Fracture Zone (TFZ) that links the North 
Volcanic Zone (NVZ) and the Kolbeinsey Ridge (KR) that extends offshore north of Iceland (Fig. 1b). Rift-zone volcanism is characterized by tholeiitic compositions, while volcanism in propagating and off-rift is transitional alkaline to alkaline in composition. The propagating Eastern Volcanic zone changes in character from tholeiitic to transitional alkaline to alkaline towards its tip south of Iceland (Jakobsson, 1972; Óskarsson et al., 1982; Óskarsson et

5 al., 1985; Thordarson \& Larsen, 2007).

Volcanism and rifting in the currently active volcanic zones are restricted to so-called volcanic systems that commonly consist of a fissure swarm with eruptive fissures and graben faults (Burchardt \& Gudmundsson, 2009; Saemundsson, 1979). Fissure eruptions in the volcanic systems are fed by subvertical dykes that form dense dyke swarms at depth and contribute to accretion of new oceanic crust by intrusion and eruption of flood basalts. Most volcanic systems also

10 host a central volcano that may produce more evolved magmas in shallow crustal magma reservoirs through fractional crystallization and recycling of hydrothermally altered crust (Saemundsson, 1979; Walker, 1966). Central volcanoes can thus be the site of explosive volcanism associated with caldera collapse and ignimbrite formation. Exposures of extinct and eroded central volcanoes reveal that, at shallow depth, central volcanoes often consist of swarms of magmatic sheets, often centrally inclined towards their source magma reservoir, so-called cone sheets or inclined sheet

15 (e.g. Burchardt et al., 2011). Such sheets usually emanate from solidified magma reservoirs, i.e. plutons, that were emplaced at paleodepths of >1 km (e.g. (Burchardt \& Gudmundsson, 2009; Furman et al., 1992; Klausen, 2004, 2006; Walker, 1974). The plutonic roots of central volcanoes are also characterised by localised contact metamorphism and remnants of associated geothermal activity (e.g. Fridleifsson, 1983; Liotta et al., 2020). 


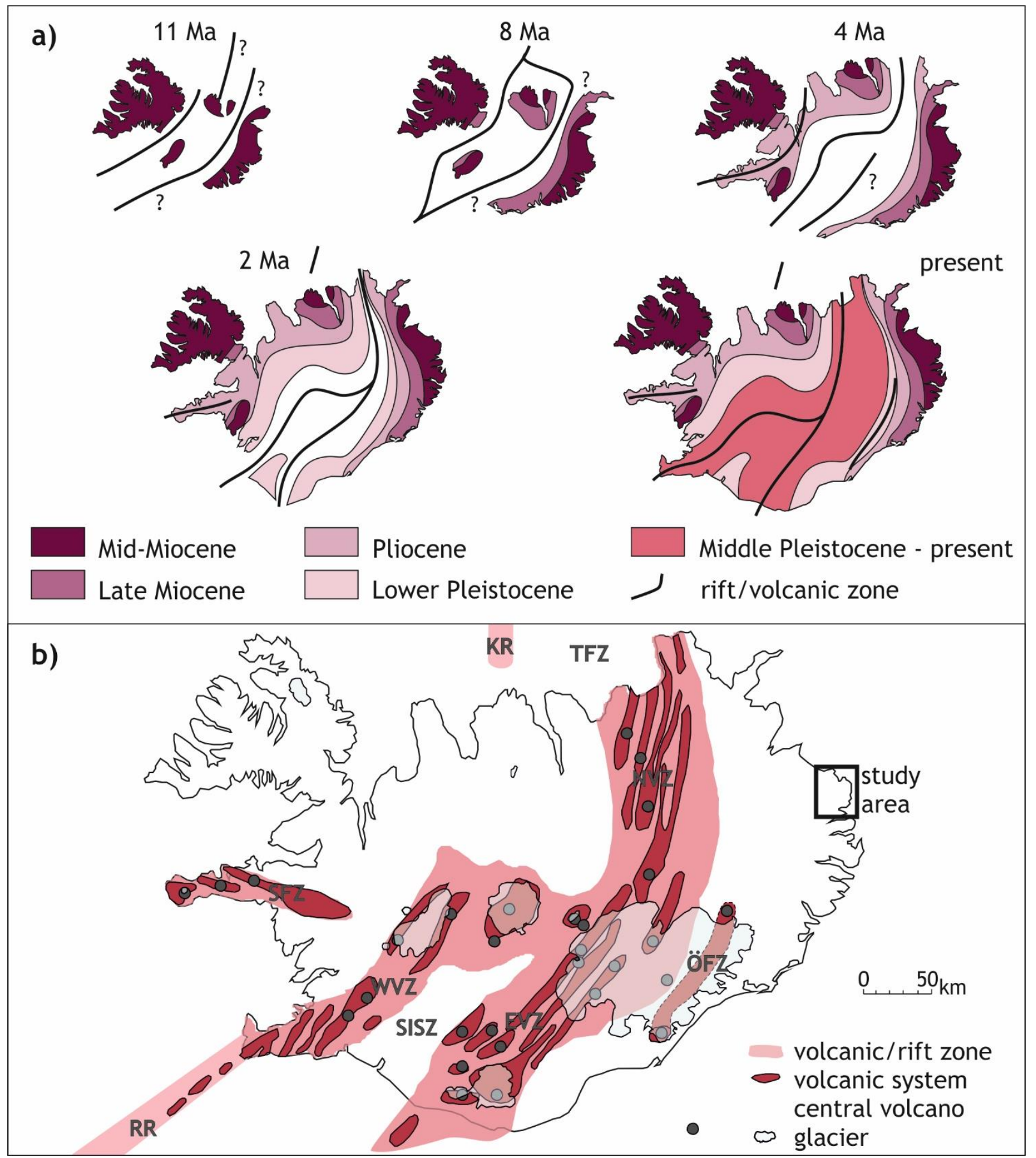

Figure 1. Geodynamic setting of Iceland through time. a) Location of past rift zones and age of the surface rocks in Iceland. Note that little is known about the rift zone configuration in the geological past. Based on e.g. Walker (1975). b) Current arrangement of rift zones, flank zones, and volcanic systems in Iceland (see e.g. Sigmundsson et al., 2020). 
A number of fossil rift zones have been identified in the Neogene areas of Iceland, interpreted to have formed through episodic jumps of the plate boundary to the east following the west-ward drift of the plate boundary relative to the Iceland plume (Fig. 1a). This process leaves behind an extinct rift zone with extinct volcanic systems, while activity transfers to a new rift zone further east (Helgason, 1984). In Eastern Iceland, flood basalts and extinct volcanic systems

5 are exposed in mountainous terrain dissected by deep fjords. Due to a general tilt of the lava pile towards the active rift zone, a succession with a cumulative thickness of 10 to $12 \mathrm{~km}$ is exposed (Walker, 1974). The lava pile is primarily composed of flood basalt lavas, some of which are widespread and can be traced over long distances and used as marker horizons (e.g. (Óskarsson \& Riishuus, 2013, 2014; Walker, 1958).

These lava horizons are mostly of basaltic composition and classified into two types, the regional flood basalts and the

10 basalts associated with the central volcanoes. Early researchers were quick to recognize that the bulk of the lava flows of eastern Iceland represented eruptions of the so-called flood basalt type (Gibson, 1963; Walker, 1964). One reason was the great geographical distribution of the lavas that could be traced across the entire eastern fjords and interpreted to be the product of large fissure-eruptions. The other reason was based on structural grounds, especially on the occurrence of extensive sheet flows of so-called simple flows (tabular flows) with plane-parallel stratification, which

15 suggested events of high effusion rates (Jerram \& Widdowson, 2005; Walker, 1971). Simple flow architecture was recognized previously in other flood basalt provinces, and their occurrence in Iceland impelled a genetic correlation between the flood basalts of eastern Greenland, the Faroes and northern Britain that today make the NAIP and are related to the activity of the Icelandic plume. In recent studies, individual lava groups have been mapped that include simple flows ( Óskarsson \& Riishuus, 2013; Óskarsson \& Riishuus, 2014; Óskarsson et al., 2017) and suggest

20 eruptions on the scale much larger than the 1783-84 Skaftáreldar (Laki) eruption that formed a compound field of lavas with a volume of more than $14 \mathrm{~km}^{3}$ (Thordarson \& Self, 1993).

Extinct central volcanoes, enveloped by flood basalts, have been studied in western and eastern Iceland and contributed to the modern understanding of the architecture of sub-volcanic plumbing systems and rift zones (e.g. Burchardt \& Gudmundsson, 2009; Carmichael, 1964; Martin \& Sigmarsson, 2010; Walker, 1958; Walker, 1963).

25 However, the area around Borgarfjörður eystri and Loðmundarfjörður (BEL) in the northern part of the eastern fjords of Iceland has received little scientific attention until recently. Based on previous studies and more than 35 years of fieldwork, we present the following comprehensive summary of the geological features found in the area. Apart from the regional geological context, our focus is mostly on the silicic rocks and the associated volcanic structures, such as collapse calderas. We realise how much of the geology of the area is still unknown, but intend to inspire colleagues to

30 explore more of this area, which is why we conclude with open questions and suggestions for future work.

\section{PREVIOUS RESEARCH}


One of the first publications to show a large silicic area within the northeast corner of Iceland with numerous centres was the geological map of Iceland in 1:600.000 of Porvaldur Thoroddsen in 1900 (Thoroddsen, 1901), later republished in 1901 and 1906. Dearnley (1954) was one of the first to produce a reconnaissance map of the Kækjuskörð area in Loðmundarfjörður, where he identified most of the silicic rocks there as parts of a shallow 5 intrusion. G.P.L. Walker, one of the pioneers of geological investigations in Neogene terrains in Iceland who worked extensively in Eastern Iceland, never went to the BEL for concise mapping, but refers to silicic volcanism in the area in his notes and unpublished maps. In the seventies of the last century the northern part of Borgarfjörður eystri was mapped for the Sheet 7 (North East Iceland) of the 1:250.000 geological map of the Icelandic Institute for Natural History and the Icelandic Geodetical Survey. In the nineteen eighties Gústafsson (1992) mapped the first volcanic 10 centre of the area, the Dyrfjöll Central Volcano, of which the Njarðvík Volcanic centre is thought to be a part of. Also, in the nineteen eighties the Kækjuskörð area was remapped by Gústafsson, Thomas, B. Lapp, and M. Lapp (Gustafsson et al., 1989). They redefined Dearnley's intrusion as a silicic eruptive centre with subaerial silicic lava flows. During this mapping campaign the existence of at least one other central volcano was inferred due to the occurrence of a massive ignimbrite sheet originating in and around the mountain Herfell to the southwest of

15 Kækjuskörð. In this century, Vogler mapped the southern part of the Breiðuvík Central Volcano (Vogler, 2014), and Guðmundsson mapped the coastal area between Borgarfjörður and Loðmundarfjörður (Gudmundsson, A. I., unpublished report). The Icelandic Institute of Natural History published a geological map in 1:100 000 of the midEastfjords from Berufjörður to Loðmundarfjörður (Óskarsson and Riishuus, 2019) and has recently mapped the BEL area. The geological map presented as part of this study (see below) is partly the result of this mapping campaign

20 combined with all the authors' observations.

Only during the last fifteen years detailed investigations into structural and petrochemical problems have begun. The possible existence of Mesozoic crust under Eastern Iceland, as inferred from geochemical investigations of zircon crystals by Paquette et al. (2007) has as yet not been confirmed. Martin and co-workers looked into the regional setting of the area during its formation, with emphasis on the formation of silicic rocks (Martin et al., 2011; Martin \&

25 Sigmarsson, 2010), while Berg and co-workers studied the age and petrogenesis of the BEL area (Berg et al., 2018; Berg, 2016). The nature and age of zircon crystals from the area was also investigated by Carley and co-workers who concluded that Iceland is not an analogue for continental formation in the Hadean (Carley et al., 2014; Carley et al., 2020), something that was proposed by Berg et al. (2014). Moreover, some of the sub-volcanic intrusions have been studied by Burchardt and co-workers (Burchardt, 2008; Burchardt et al., 2011) and Saubin et al. (2019).

\section{RESULTS}




\subsection{Regional geological context}

The northern part of the Eastern fjords has undergone less burial and subsidence in comparison to areas in the mid-and southeastern Iceland, as evident from the low degree of metamorphism of the bedrock (Walker, 1974). The uppermost Chabazite-Thomsonite zeolite zone that forms at temperatures of about $60^{\circ} \mathrm{C}$ within the olivine basalts, appears at

5 elevations of about 400 m.a.s.l., while this zone is found at higher elevations in the south or at 600-900 m.a.s.l., where exhumation amounts to $500 \mathrm{~m}$. The zeolite zones are likely raised a few hundred meters above the volcanic centres in BEL following the contact metamorphic aureoles of the intrusions underlying the volcanic complexes, evident from the occurrences of minerals such as calcite and aragonite that form at higher temperatures around these centres. Given that the top of the original surface is found about $600 \mathrm{~m}$ above the base of the Chabazite-Thomsonite zone, the highest

10 mountain peaks of BEL (e.g. Dyrfjöll reaching elevations of 1134 m.a.s.l.) are close to the original land surface (cf. Walker, 1974). This is further corroborated by the dyke density that is less than 4\% at sea level in BEL (Fig. 2), indicating that only the upper part the dyke swarm associated with the BEL volcanic complexes is observed (cf. Walker, 1974). Conversely, dyke density in the dyke swarms to the south, in mid-eastern Iceland reaches $8 \%$ at sea level and decreases to $2-4 \%$ at elevations of 700-900 m.a.s.l. (Fig. 2d; Walker, 1974).

15 The inclination of the lava pile in the BEL is multidirectional in contrast with the prominent westward to southwestward regional inclination of the strata in eastern Iceland (Fig. 2b and c). Deviations from this regional pattern south of BEL are local and associated with extinct central volcanoes. In contrast, the areal extent of the BEL dip anomaly is about $600 \mathrm{~km}^{2}$. 


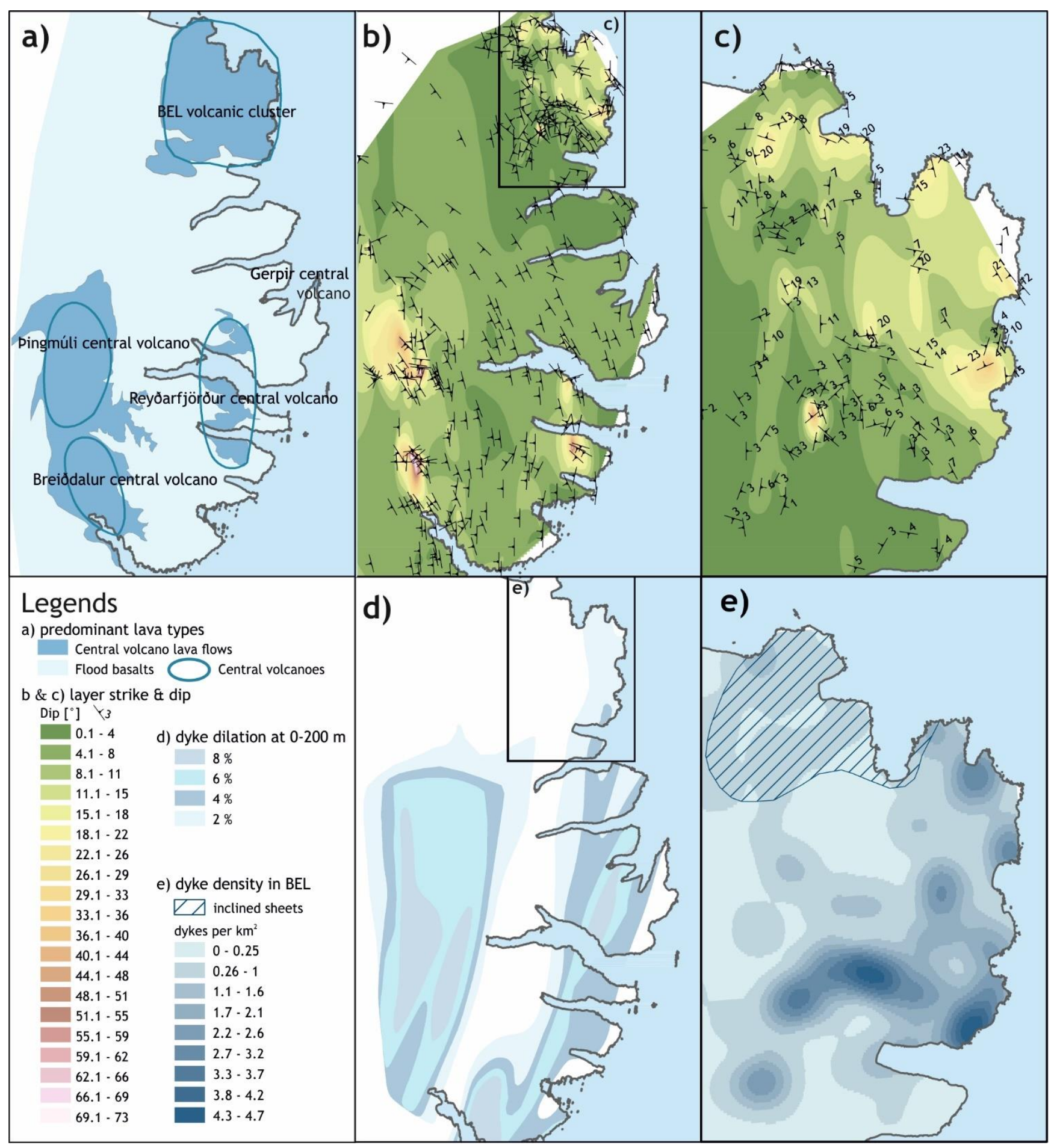

Figure 2. Overview maps of eastern Iceland and Borgarfjörður eystri and Loðmundarfjörður (BEL). a) The distribution of lava flows by type morphology. b) Strike and dip of the strata in eastern Iceland. Note the anomalies in dip directions that occur 
around the central volcanoes. c) A close-up of the BEL area showing the distribution of dip directions. d) Map showing dyke dilation at 0-200 m, associated with the occurrence of dyke swarms. e) A close-up of the dyke density in the BEL area.

\subsection{Geology of the volcanic centres of BEL}

The BEL area hosts a cluster of volcanoes presently dissected by deep fjords, and three individual central volcanoes,

5 Dyrfjöll/Njarðvík, Breiðuvík, and Herfell, have previously been distinguished based on geography, the location of collapse calderas, and the distribution of smaller eruptive centres like Kækjuskörð (Gustafsson et al., 1989). However, further analysis of field relationships of rock units and radiogenic dating show that volcanism in the area was roughly contemporaneous (Berg, 2016; Burchardt et al., 2011). Hence, the established distinction of central volcanoes may have to be revised. To begin with, we will therefore describe the geological features according to the established

10 volcanic centres (Section 4.1) before we re-evaluate the concept and distinction of individual central volcanoes in Section 5. All observations are included in the new geological map of the area (Fig. 3). 


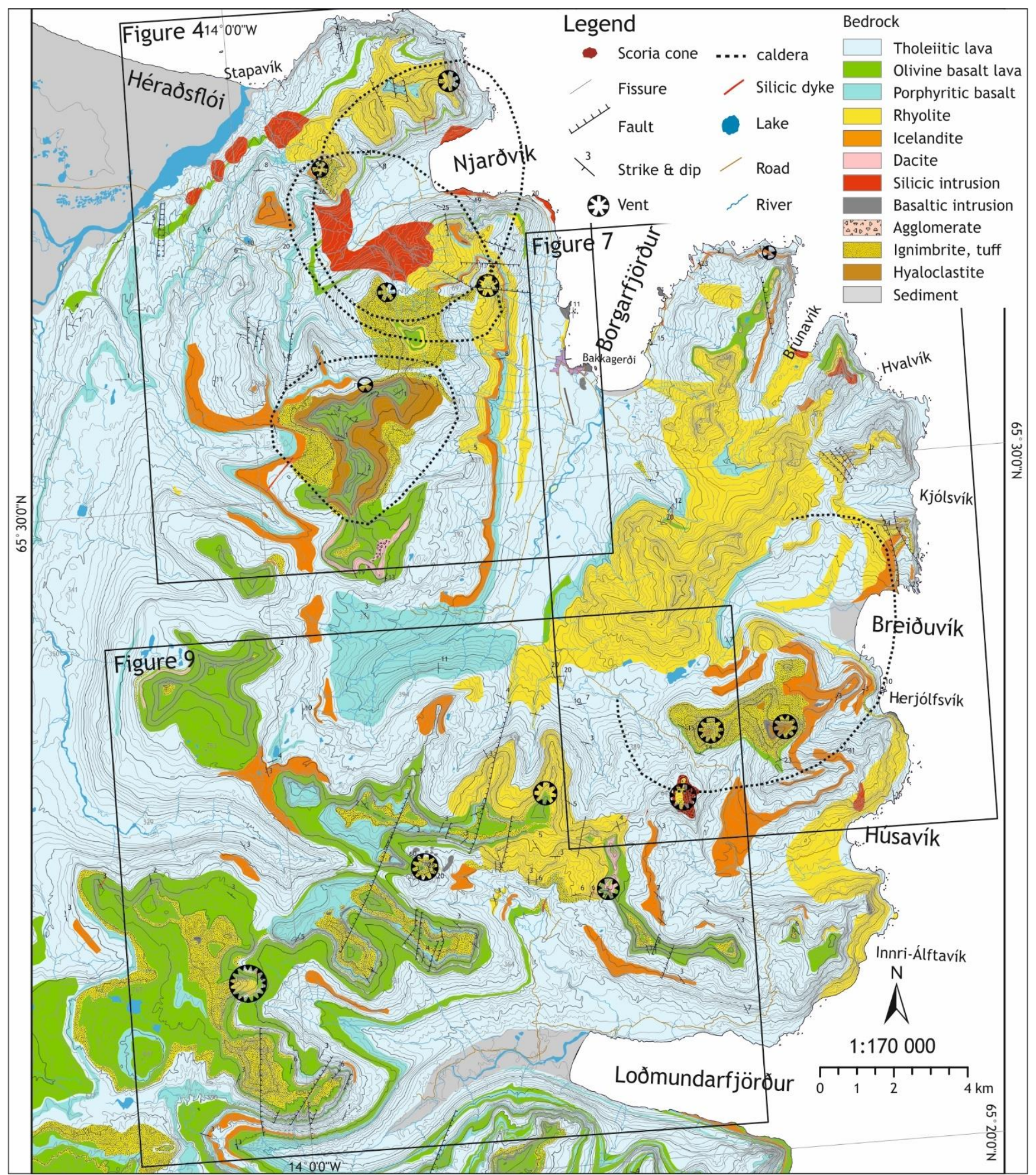

Figure 3. Geologial map of the Borgarfjörður - Loðmundarfjörður (BEL) area. Boxes indicate the locations of the detailed maps 
in Figs. 4, 7, and 9.

\subsubsection{Njarðvík and Dyrfjöll}

The rocks exposed in the mountains around the cove of Njarðvík in the north of the area (Fig. 4) document a multiphase evolution. The oldest exposed rocks that can be ascribed to central-volcanic activity are thin (mostly 1-5 m

5 thick) tholeiitic lavas (Lower and Upper Basalt Series of Gustafsson (1992)). These tholeiites are intercalated with regional flood basalt lavas on the eastern slopes of Héraðsflói valley, just below the mountain pass of Vatnsskarð. The absence of erosional surfaces and paleosols between the tholeiite lavas indicate a high eruption frequency. Around the cove of Njarðvík, the basaltic lavas are tilted (Fig. 5e), forming a depression or downsag caldera with a centre close to the back of the valley (Figs. 3 and 4; see also Section 4.5).

10 Early basaltic volcanism changed to bimodal, as evident from voluminous rhyolitic intrusions and associated extrusive rocks that frequently contain blobs of mafic magma, and from composite dykes. Several rhyolitic sills and a larger subvolcanic intrusion formed in the basaltic lavas in Njarðvík and the surrounding mountains (Fig. 5; Njarðvík Silicic Complex of Gústafsson (1992); see also Section 4.4). These rhyolitic intrusions in turn fed numerous inclined sheets, dykes and sills (see Section 4.3), as well as some effusive and explosive eruptions. The main rhyolitic intrusion is

15 exposed along the coast and the valleys in Njarðvík where it forms a mostly concordant dome-shaped intrusion with some faulted wall contacts (Fig. 5a). The culmination of the dome was probably situated in the Njarðvík cove itself. In the mountains along the northern shore, rhyolite magma intruded at a depth of approximately $300 \mathrm{~m}$ beneath the palaeosurface and reaches an exposed thickness of about $100 \mathrm{~m}$ (Fig. 5a). To the south in Stórskriðudalur, the maximum thickness of the rhyolite intrusion is 250 to $300 \mathrm{~m}$. While most of the intrusion is dense and sometimes

20 columnar jointed, its shallower parts exhibit features typical for extrusive rhyolite, such as lithophysae and flow folds. Hence, the intrusion likely pierced the surface of the volcano and partly extruded. A rhyolitic ring dyke extending from the main intrusion upwards into the mountains surrounding Njarðvík fed rhyolitic lava flows and pyroclastic rocks (Figs. 5a, c, d, e). Four of these eruption sites are exposed at the peaks of the mountains around Njarðvík and exhibit remarkable exposures of rhyolitic feeder dykes, agglomerates, pyroclastics, and lava flows (Fig. 5a, c, d, e). In

25 southern Njarðvík, a rhyolitic ignimbrite that contains petrified wood occurs locally with a maximum thickness of 150 $\mathrm{m}$ and dips towards the valley with up to $30^{\circ}$ (Náttmálahnúkur; Fig. 5f). 


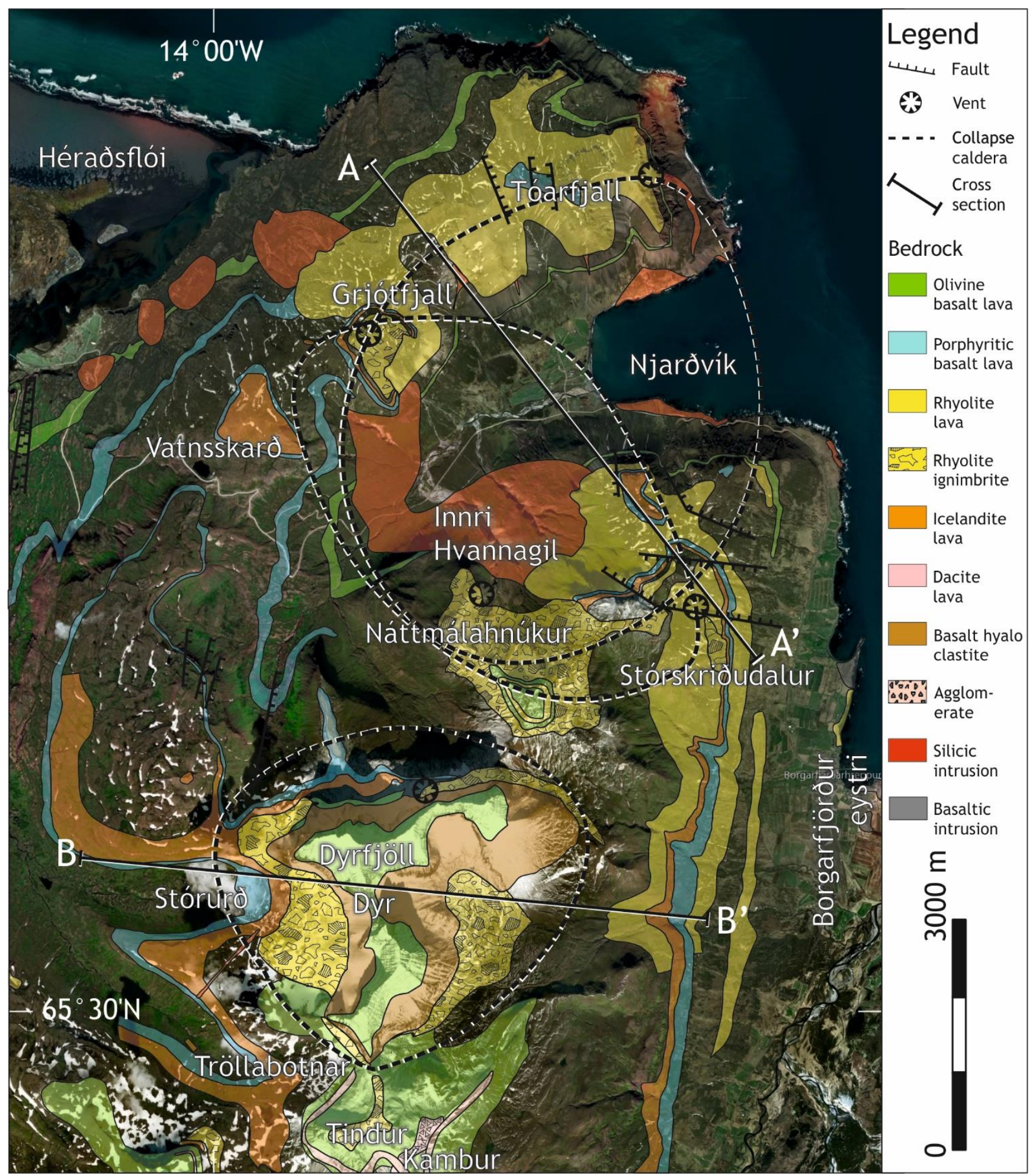

Figure 4. Geological map of Njarðvík and Dyrjöll. Location see Fig. 3. Satellite image from 2009 accessed though Bing Maps. 
The bimodal phase culminated in an ignimbrite-forming eruption ca. $5 \mathrm{~km} \mathrm{SSW}$ of Njarðvík. During the eruption, the roughly circular Dyrfjöll collapse caldera with a maximum diameter of $4 \mathrm{~km}$ formed bound by steeply inward-dipping ring faults (Figs. 4 and 6; see also Section 4.5). While the bottom of the caldera is not exposed, an agglomerate-filled vent area with welded ignimbrite is exposed at the northern caldera margin. The caldera is filled by at least $30 \mathrm{~m}$ of

5 pink to green ignimbrite that is welded at its base and overlain by up to $3.5 \mathrm{~m}$ of air-fall deposits (Fig. 6f).

Numerous basaltic, composite, and some silicic dykes and cone sheets intruded the rhyolitic intrusions and basaltic and rhyolitic lavas in Njarðvík and northern Borgarfjörður eystri (Figs. 5b and d; Burchardt et al., 2011; see Section 4.4.2). These sheet intrusions document the shift from bimodal to mostly basaltic magmatism. Extrusive activity during this phase produced some basaltic lava flows that cover the Náttmálahnúkur ignimbrite (Fig. 5f). At the same time, the lake

10 within the Dyrfjöll caldera depression filled with at least $350 \mathrm{~m}$ of basaltic hyaloclastite, pillow breccia and pillow lava during a few eruptions (Fig. 6). These lava flows are part of the Jónsfjall olivine basalt group that covers the entire area (see Section 4.3). Dips of the hyaloclastite towards the caldera centre indicate that it was erupted at the caldera margin. Basaltic dykes cross-cutting the caldera infill are mostly parallel with the caldera walls (Gústafsson, 1992). Once the caldera lake was filled, tholeiite, olivine basalt, and one $50 \mathrm{~m}$ thick dacite lava flow buried the caldera. The dacite flow

15 was erupted from an agglomerate-filled vent at Kambur and is overlain by basaltic lavas and pyroclastic rocks at Tindur. Notably, the rocks of Tindur and Kambur immediately south of the Dyrfjöll caldera dip at up to $19^{\circ}$ to the E. 


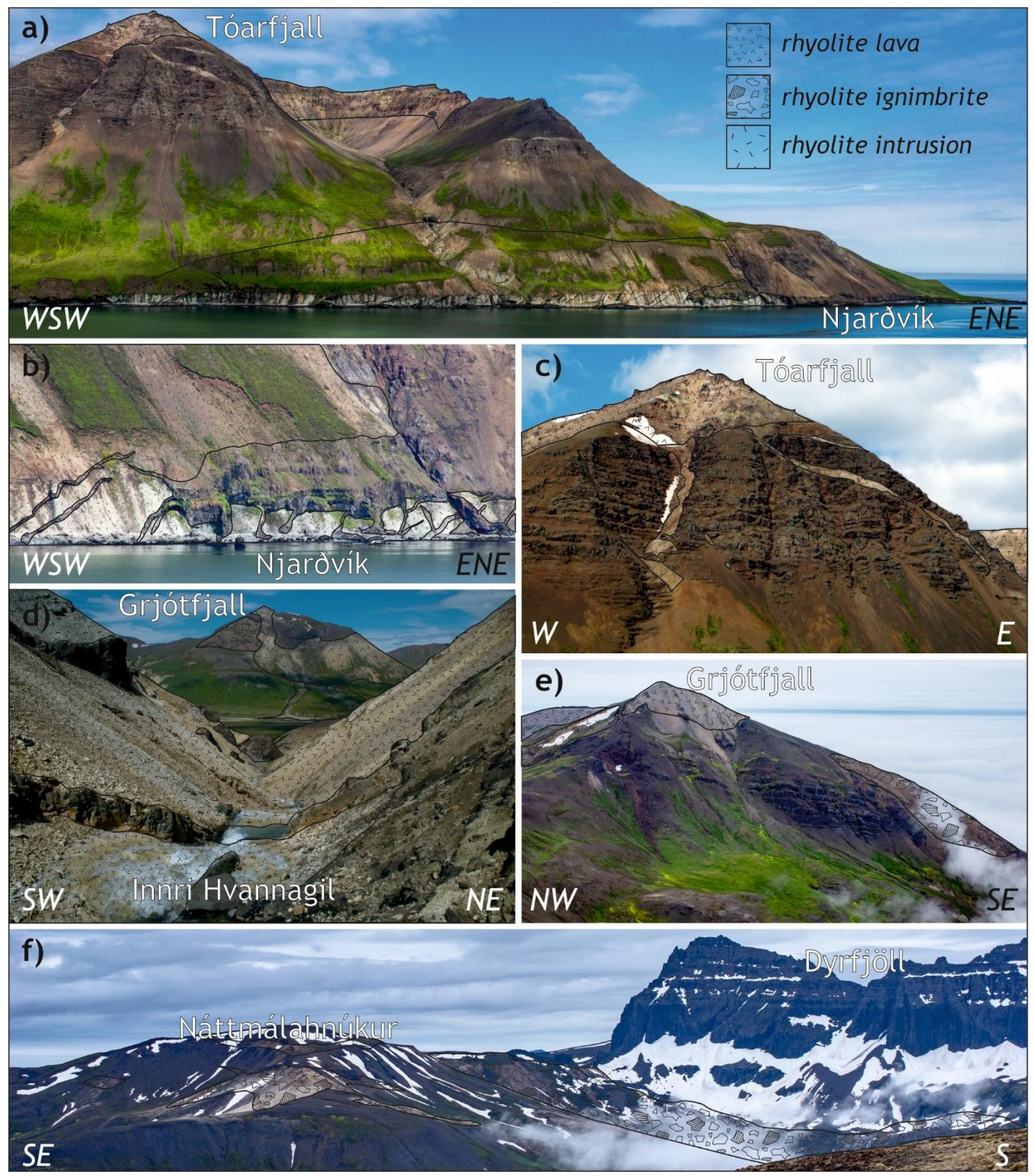

Figure 5. Annotated field photographs illustrating the geology of Njarðvík. For locations see Fig. 4. a) On the northern shore of 
Njarðvík, white coloured intrusive rhyolites are intruded by black basaltic cone sheets and overlain by grey-brown basaltic lava flows. The mountain peaks around the bay (e.g. Tóarfjall) are formed by rhyolitic lava. b) The Njarðvík sill (Burchardt, 2008) is formed by basaltic cone sheets intruding the white coloured intrusive rhyolite at the northern shore. c) The peak of Tóarfjall is formed by rhyolitic lava fed by rhyolitic dykes cutting through basaltic lava flows. d) The sub-volcanic rhyolite exposed in Innri

5 Hvannagil is cut by basaltic dykes and cone sheets. e) The peak of Grjótfjal is formed by an eruptive vent with rhyolitic pyroclastic rock. The underlying basaltic lavas dip towards the Njarðvík bay as a result of downsagging (see Section 4.5.1). f) View towards Dyrfjöll and Náttmálahnjúkur with the two ignimbrites marked. 

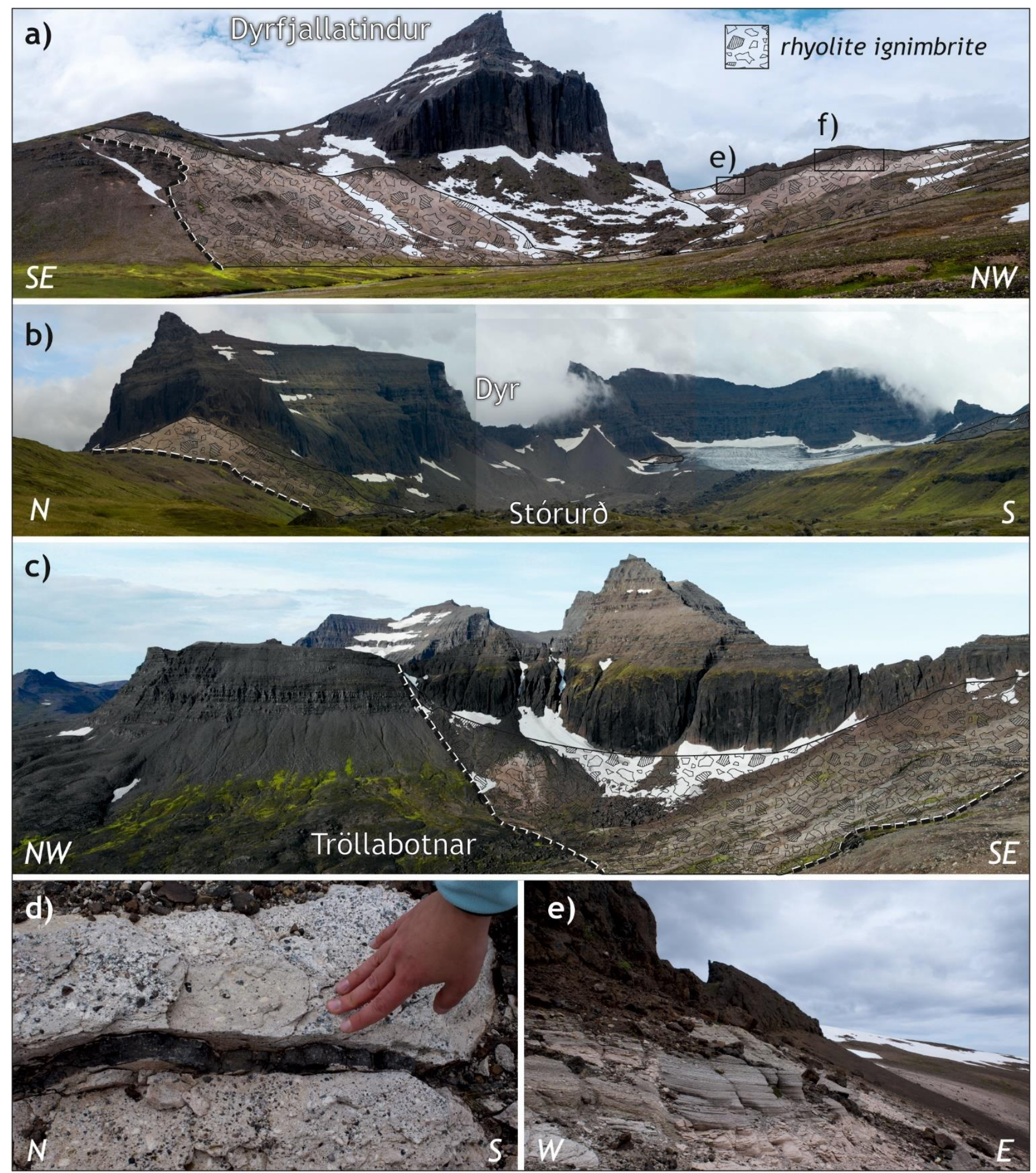

Figure 6. Annotated field photographs illustrating the geology of Dyrfjöll. For locations see Fig. 4. a) to c) Views of the Dyrfjöll 
caldera rocks, including the caldera margin (dashed line), the caldera-filling rhyolitic ignimbrite, the hyaloclastite (massive brown rock unit) erupted in the caldera lake, and the flat-lying olivine basalt lava flows that covered the entire volcanic complex, forming the mountain peaks. d) thin basaltic dyke cuttting through the Dyrfjöll ignimbrite that contains white pumice and dark basaltic lithics. See hand for scale. e) Layered airfall deposits at the top of the Dyrfjöll ignimbrite. Thickness here approximately 2 m. The

5 brown rocks overlying the airfall deposits are the base of the basaltic hyaloclstite erupted in the caldera lake. Locations of d) and e) marked in a).

\subsubsection{Breiðuvík}

The volcanic stratigraphy of the area between Borgarfjörður eystri and Loðmundarfjörður (Breiðuvík volcano; Fig. 7) strongly resembles that of Njarðvík and Dyrfjöll to the north. Early central-type tholeiitic lava flows are overlain by

10 voluminous rhyolitic lavas and at least two lava domes, many of them unmapped to this day (Fig. 8). The stratigraphically oldest silicic rocks can be found in and around Húsavík and were potentially erupted from a, noweroded, eruptive centre to the east. A rhyolitic ignimbrite at the shore south of Húsavík was dated at $13.10 \pm 0.20 \mathrm{Ma}$ (Martin et al., 2011).

In Breiðuvík, Moldarbotnar, Mosdalur, and along the northern side of Húsavík, flat-lying icelandite lavas intercalated

15 with tholeiite lavas form the base of predominantly silicic volcanic rocks. Rhyolitic ignimbrite sheets occur between tholeiitic lavas east of Grenmor and in Kerlingarfjall (Vogler, 2014). This bimodal volcanic succession is overlain by at least one olivine basalt flow that can be found in Herjólfsvíkurvarp, Húsavíkurheiði, and Víknaheiði underlying the Hvítserkur ignimbrite. The Hvítserkur ignimbrite is the infill of a pronounced collapse caldera that is described in detail in Section 4.5 (Fig. 8a-c). The ignimbrite is overlain by at least $70 \mathrm{~m}$ of fine-grained lake sediments that contain

20 a $5 \mathrm{~m}$ thick distal rhyolitic ignimbrite (see description of the caldera) (Fig. 8c). Numerous dykes and some sills crosscut the ignimbrite and the lake sediments (Fig. 8b and c), most of them are composed of olivine basalt (see also Section 4.3). Some of the dykes are connected to vents feeding the pillow lavas and hyaloclastite forming the summit of Hvítserkur. The very summit of Hvítserkur is formed by subaerial basaltic lava (Fig. 8b).

In the upper Breiðuvík valley, a conspicuous light-coloured hill called Hvítafjall occurs in what was probably the

25 central part of the caldera (Fig. 8f). Hvitafall consists of strongly altered rhyolite breccias that cut the gently-dipping lavas of the caldera floor at steep angles. Hvítafjall is therefore most likely the remnant of an intra-caldera dome, although the timing of its formation relative to the ignimbrite is unclear.

Downfaulting of the cliff east of Grenmore (Vogler, 2014) postdating caldera formation and a succession of thin basalt lavas dipping steeply towards the sea north of Húsavík indicate that the Breiðuvík volcano had steep flanks during its 30 lifetime. 


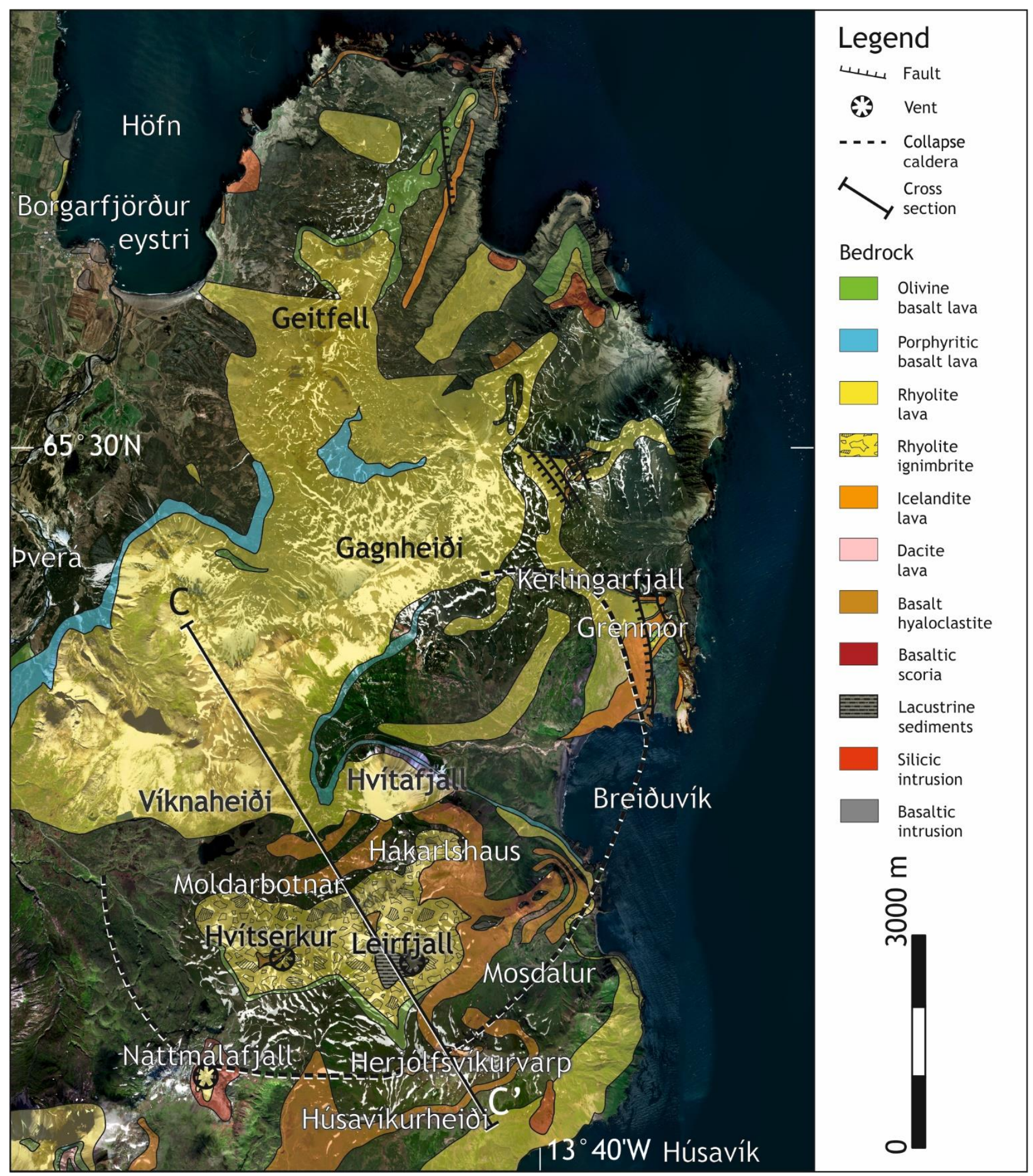

Figure 7. Geological map of the Breiðuvík volcano. Location see Fig. 3. Satellite image from 2009 accessed though Bing Maps. 


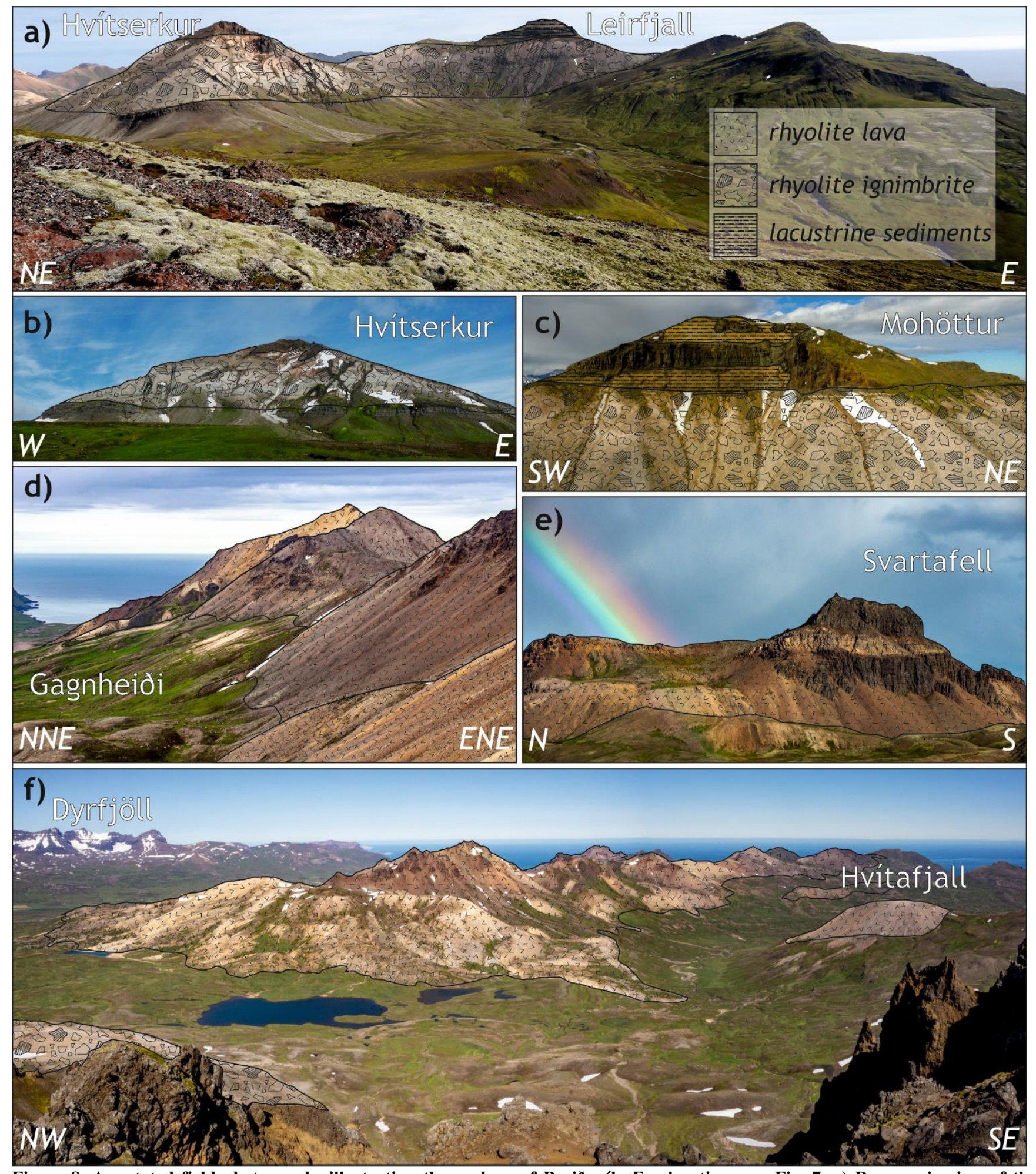

Figure 8. Annotated field photographs illustrating the geology of Breiðuvík. For locations see Fig. 7. a) Panoramic view of the 
Breiðuvík caldera with the caldera-infill Hvítserkur ignimbrite and the overlying caldera lake sediments marked. b) Southern flank of Hvítserkur showing the landmark ignimbrite crosscut by dark basaltic dykes. The top of the mountain is formed by basaltic hyaloclastite erupted in the caldera lake overlain by subaerial lavas. c) southern flank of Leirfjall. The Hvítserkur ignimbrite is overlain by clastic lacustrine sediments intruded by basaltic dykes and sills. d) The colourful mountains near

5 Gagnheidi consist of rhyolitic lava flows. e) Thick rhyolitic lava flow forming the top of Svartafell. the layered appearance is a result of different jointing directions in the rhyolite lava. f) View from the top of Hvítserkur. The mountains between Breiðuvík and Borgarfjörður eystri consist of rhyolitic lavas and lava domes. Hvítafjall is the remnant of a lava dome.

\subsubsection{Kakjuskörð}

The area west of the Breiðuvík volcano and south of Dyrfjöll is characterised by a bimodal volcanic suite ascribed to

10 the Kækjuskörð volcano (Fig. 9; Gustafsson et al., 1989). Kækjuskörð comprises a series of rhyolitic and intermediate extrusive rocks and contemporaneous central-volcano type and regional basaltic lavas that were described by (Gustafsson et al., 1989). The oldest exposed rocks in the area are central-type tholeiite flows that dip at low angles $\left(<10^{\circ}\right)$ towards Skumhöttur. Within these tholeiites, a few icelandite lavas occur, one particularly prominent icelandite flow can be traced from a small eruption site in Náttmálafjall all around Húsavík and to the north flanks of

15 Loðmundarfjörður and from there into Norðdalur. The basaltic lavas directly underlay the olivine basalt lava at the base of the Breiðuvík caldera. Tholeiitic and olivine basalt lavas are intercalated with a number of rhyolitic ignimbrites, several rhyolitic lava flows, and a dacite flow that occur locally and originate from eruption sites that progress in age from north to south (Fig. 10).

Rhyolitic volcanism in the area started with an up to $40 \mathrm{~m}$ thick flow at Kollutungur. Two rhyolitic ignimbrites are

20 exposed locally in the vicinity of Skumhöttur (Fig. 10b), Orustukambur ignimbrites I and II (Gustafsson et al., 1989). The older one is about $30 \mathrm{~m}$ thick and contains up to two metre long, silicified tree fragments. The younger Orustukambur II ignimbrite can be found as a thick (ca. $80 \mathrm{~m}$ ) sheet in Kerlingardalur and is suggested to be the product of a dome-collapse at Skúmhöttur (Gustafsson et al., 1989). The overlying Kækjuskörð rhyolite originates from an eruption site at Skúmhöttur, covers an area of $15 \mathrm{~km}^{2}$, and reaches a maximum thickness of $300 \mathrm{~m}$ (Fig. 10b).

25 The Kækjuskörð rhyolite is covered by two younger rhyolite flows, Priggjahnjúkafjall rhyolites I and II (Fig. 10a). These flowed down-hill for a distance of $1 \mathrm{~km}$ from Priggjahnjúkafjall and reach thicknesses of 50 and $30 \mathrm{~m}$, respectively. The eruption site of Priggjahnjúkafjall rhyolite II is exposed at the mountain with the same name (Fig. 9). Some distal pyroclastic deposits cover the Priggjahnjúkafjall rhyolite II.

In Kerlingardalur, a proximal rhyolitic ignimbrite occurs locally and discordantly (Fig. 10c; previously described as 30 tuff ring by Thomas, 1990), which we interpret as the product of a caldera collapse (see Section 4.5). The ignimbrite was subsequently intruded by basaltic sills and dykes. The age relationship between the Kerlingardalur and other ignimbrites remains unclear, but it is possible that the Kerlinhardalur ignimbrite and Orustukambur ignimbrite II originate from the same event (see Section 4.5). 
The rhyolites in the area are covered by olivine basalts (see Section 4.2). The remnants of a basaltic fissure eruption are exposed in Kækjuskörð, and the area is cut by an up to $200 \mathrm{~m}$ wide and $1 \mathrm{~km}$ long basaltic dyke swarm (see Section 4.3.1). Following the eruption of these basalts, a dacite flow was erupted from a feeder dyke exposed in Skúmhattardalsbrik. From there, the dacite lava flowed to the south for a distance of $1.5 \mathrm{~km}$ and was subsequently

5 covered by the Herfell ignimbrite.

\subsubsection{Herfell}

The geology around Loðmundarfjörður (Fig. 9) resembles the basic stratigraphy of the areas described above. At the base of the stratigraphy, tholeiitic lava flows are intercalated with at least one (locally two) icelandite flows. One of them appears to be the same that occurs further north (see Section 4.3). In Norðdalur, this prominent icelandite flow

10 locally thickens towards the closure of the valley.

Up sequence, two rhyolitic ignimbrites are exposed as concordant sheets in between basaltic lavas, testifying to a flat landscape covered by basaltic lavas at the time of deposition. The ignimbrite sheet at about $750 \mathrm{~m}$ above sea level likely originated from the mountain Tóarhnjúkur, where air fall deposits with large lithics are exposed (see also Section 4.5). This ignimbrite can be traced from Tóarhnjúkur towards the north and northeast at least to Kerlingardalur

15 (Fig. 9). At elevations of $900 \mathrm{~m}$ above sea level, the Herfell ignimbrite is exposed in the western and northern parts of Loðmundarfjörður. The Herfell ignimbrite was first described by Dearnley (1954) and erupted at $12.40 \pm 0.12 \mathrm{Ma}$ (Berg, 2016). In Norðdalshnjúkur, a vent related to the Herfell ignimbrite is exposed with a base at about $700 \mathrm{~m}$ a.s.l, (Fig. 10d; see also Section 4.5). At Norðdalshnjúkur and Herfell, the Herfell ignimbrite is partly welded and reaches its maximum thickness of $120 \mathrm{~m}$. From west to the east, the ignimbrite occurs as a concordant sheet on the mountains of

20 Herfell, Norðdalshnjúkur, Miðfell, Kallfell/Karlfell, Hvannstoðseggjar, Bungufell and Skælingur (Fig. 9). The thickness of this ignimbrite sheet is at a maximum of about $120 \mathrm{~m}$ around the mountain Norðdalshnjúkur and decreases to the east, still having a thickness of about 60 at the easternmost outcrop in Skælingur. No prominent outcrops of this ignimbrite are found in the mountains to the south of Loðmundarfjörður. There, only relatively thin, distal ignimbrite deposits are intercalated between basaltic lava flows. Hence, the bulk of the Herfell ignimbrite was deposited towards the NE. Olivine basalt dykes cut through the ignimbrite and fed lava flows (see Section 4.3). 


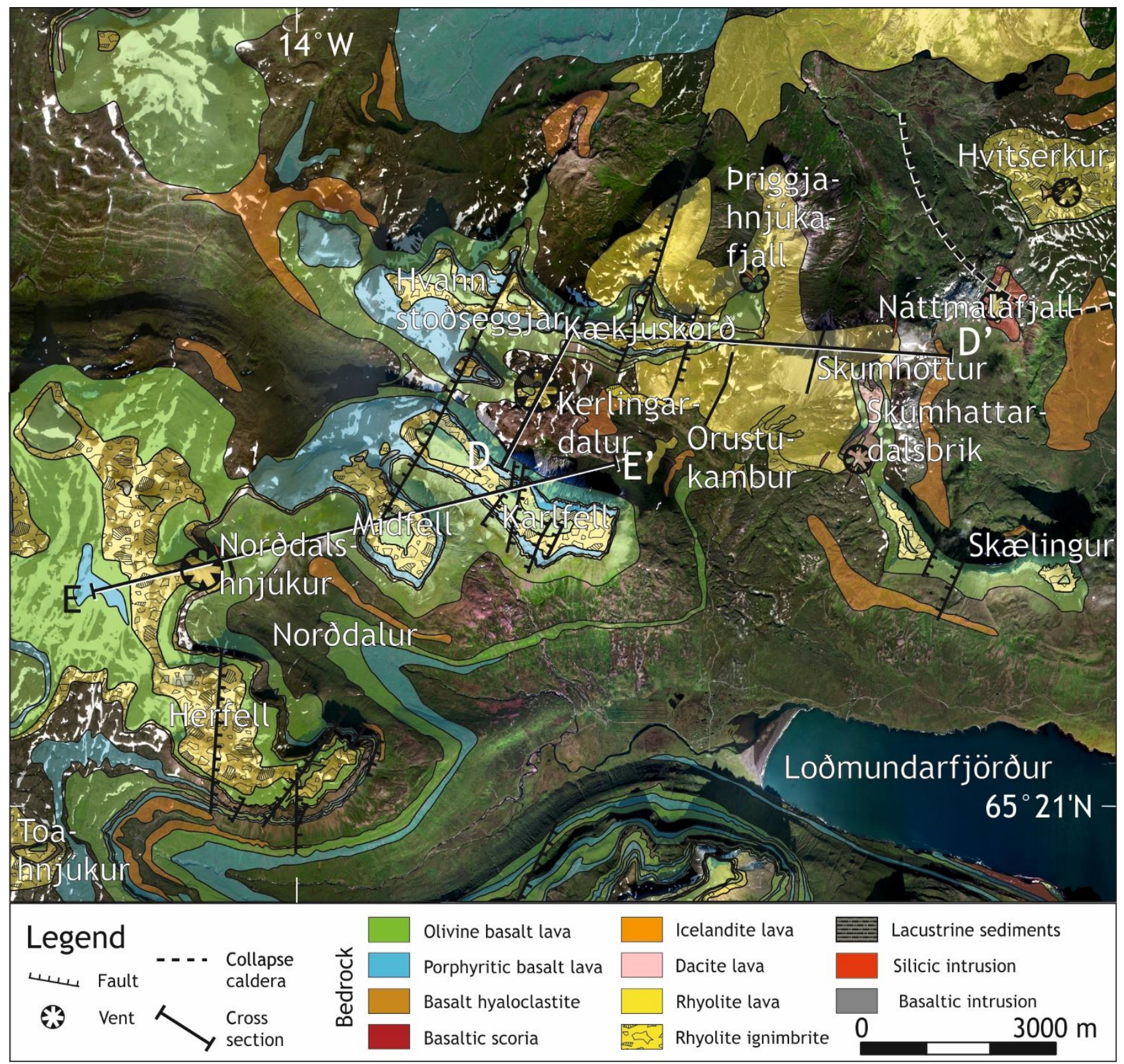

Figure 9. Geological map of the area west and north of Loðmundarfjörður. Location see Fig. 3. Satellite image from 2009 accessed though Bing Maps. 


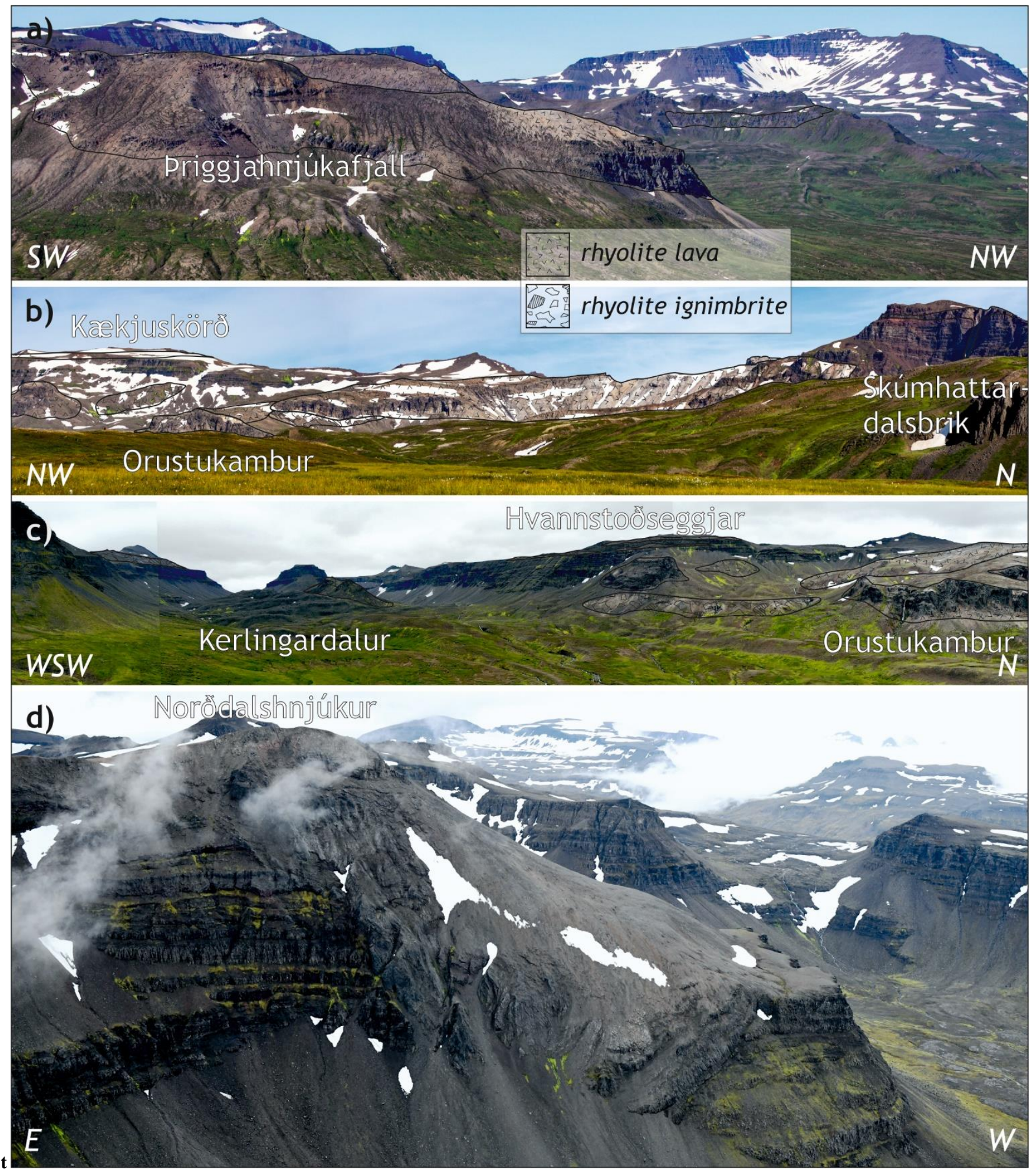

Figure 10. Annotated field photographs illustrating the geology of the area in Fig. 9. a) the Priggjahnjúkafjall rhyolites I and II 
were erupted north of Skúmhattardalsbrik and flowed northward. b) Panoramic view of the rhyolite lavas and ignimbrites around Orustukambur. Also note the feeder dyke and lava flow of dacite in Skúmhattardalsbrik. c) Continuation of the panoramic view in b, looking into Kerlingardalur. d) Unmanned Aerial vehicle (drone) photograph of a large vent structure in Norðdalshnjúkur that is connected to the Herfell ignimbite.

\section{$5 \quad 4.3$ Regional flood basalts}

The flood basalts in the study area correlate with the lower stratigraphy of Reyðarfjörður, mapped by Walker (1959), beginning below the Gerpir porphyritic group and extending up to the Hólmar olivine basalt group. A sequence of relatively thick tholeiites form the lowermost 300-400 meters, while the upper part of the sequence is formed predominantly by regional olivine basalts and local groups of olivine basalt, thin tholeiitic and porphyritic flows,

10 intercalated with the silicic lavas and tuffs from the central volcanoes. The Jónsfjall olivine basalt group described in Óskarsson \& Riishuus (2013) is a local group and extends from Loðmundarfjörður to Borgarfjörður eystri. The lava flows within this group flowed into the caldera-lake in the Dyrfjöll volcano forming the hyaloclastites that mark the central portion of Dyrfjöll mountain (see Section 4.5.2). The Herfell ignimbrite is covered by olivine basalts that correlate both stratigraphically and paleomagnetically with the Hólmar olivine basalt group, a widespread group

15 described in Óskarsson \& Riishuus (2013).

This stratigraphy indicates that volcanism seems to have largely ceased in the area after the Hólmar event, while it continued extensively to the south, forming a stack over 2,000 meters in the Thingmuli and Breiðdalur volcanic systems (Óskarsson \& Riishuus, 2019).

\subsection{The sub-volcanic plumbing system}

20 Post-volcanic glacial erosion of the area has exposed sections as deep as $1100 \mathrm{~m}$ into the flanks and upper volcanic plumbing system of the volcanic centres and their surroundings. In this section we give an overview of the wealth of sub-volcanic intrusions we have encountered in the area.

\subsubsection{Dyke swarms}

Althought the BEL area is less deeply eroded than southeast Iceland where erosion levels reach up to $2 \mathrm{~km}$ (Walker,

25 1974), dykes do frequently occur at all elevations in our study area, and we estimate the density of subvertical dykes to reach 3-4\% (cf. Lapp, 1990; Fig. 2). The orientation of dykes in BEL shows a NNE strike, with a slightly more northerly strike towards the east in BEL and a slightly more north easterly strike reported for the Kækjuskörð area (Fig. 11; this study; Burchardt et al., 2012; B. Lapp, 1988; M. Lapp, 1990b; Thomas, 1988; Gudmundsson, A. I., pers. comm.). However, we note that consistent mapping of the dykes in BEL is necessary in order to draw conclusions

30 about the existence of dyke swarms, the intrusion density, and the connection to dyke swarms from volcanic systems to the south of BEL. 


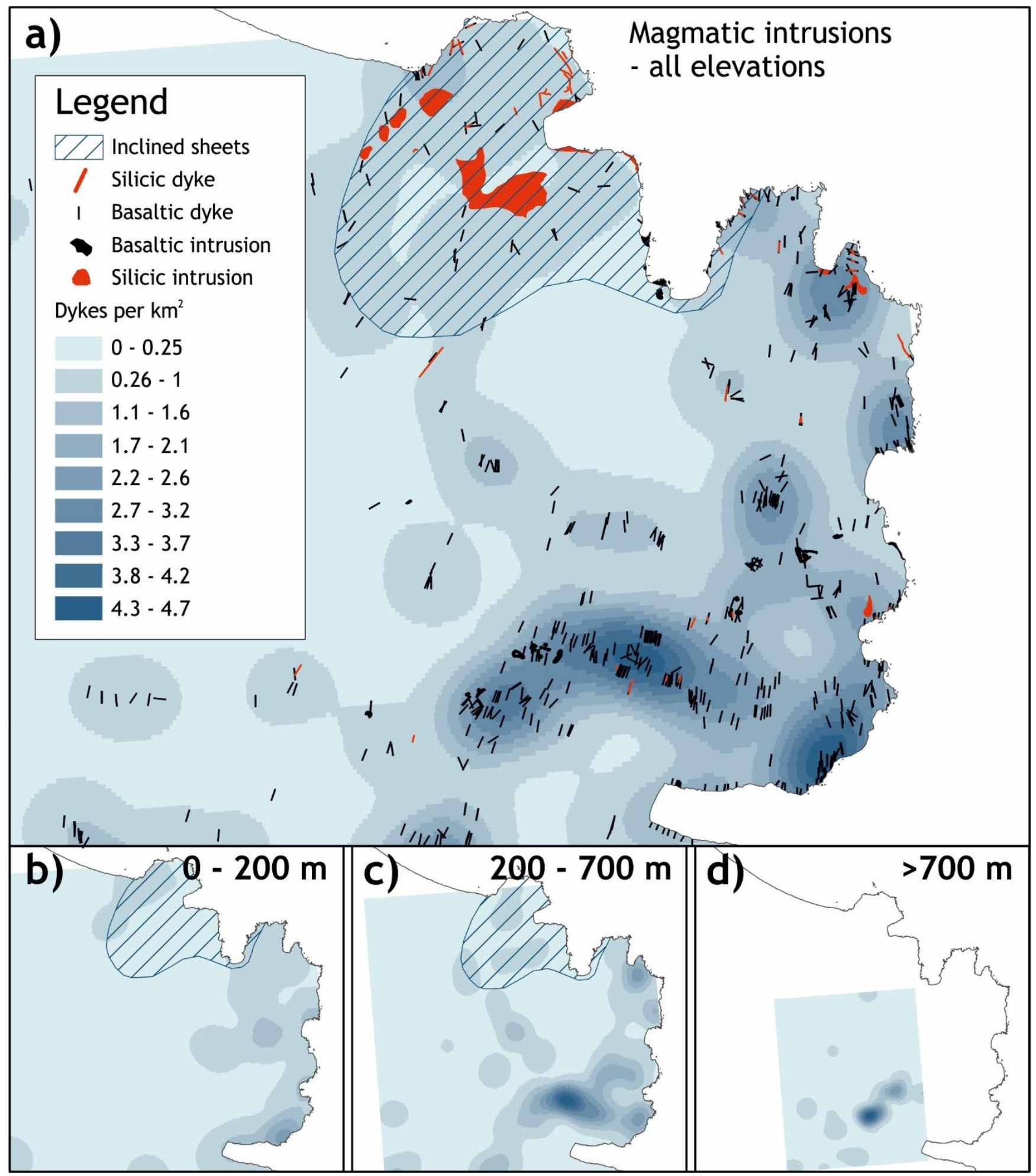

Figure 11. Density and distribution of magmatic intrusions in BEL at a) all elevations, b) 0-200 m, c) 200-700 m, and d) above 700 


\section{m above sea leavel.}

\subsubsection{Inclined sheet swarms}

Inclined (cone) sheets, i.e., moderately dipping sheet intrusions with a sub-circular shape in map view and converging to a common source magma chamber are prevalent in Njarðvík and Borgarfjörður eystri (Figs. 5, 11, and 12b, c;

5 Burchardt et al., 2011). They are mostly basaltic in composition and crosscut the silicic and basaltic rocks.

The cone sheets belong to several swarms that were fed from different locations in the area. The most pronounced cone-sheet swarm originated from a magma reservoir at about 1-2 km depth beneath the Njarðvík valley (Burchardt et al., 2011). Another, contemporaneous cone-sheet swarm converges towards a magmatic source reservoir beneath the Borgarfjörður valley (Burchardt et al., 2011). Additional, overlapping inclined sheet swarms to the $\mathrm{N}$ and $\mathrm{E}$ of

10 Njarðvík indicate the widespread distribution of volcanism. Hence, volcanism likely occurred in overlapping centres or a larger volcanic cluster that is now dissected by the Borgarfjörður eystri fjord.

\subsubsection{Other sub-volcanic intrusions}

Sub-volcanic intrusions of different types occur frequently in the study area (Fig. 11). Here, we will name just a few examples, as these intrusions are subject to ongoing research.

15 Sills are the most common form of intrusion apart from dykes and cone sheets. The best studied sills in the area are the Njarðvík sill that is fed by basaltic cone sheets emplaced close to sea level in Njarðvík (Fig. 12c; Burchardt, 2008) and the rhyolitic Landsendi sill exposed between Njarðvík and Borgarfjörður eystri (Saubin et al., 2019). Both sills are examples of concordant sheet intrusions emplaced into the lava flows and sub-volcanic intrusions of their associated volcanoes. Other sills that are currently investigated can be found in the Hvítserkur ignimbrite and the overlying lake

20 sediments of the Breiðuvík caldera (Fig. 12d, f; Burchardt et al., submitted). In addition, there are a multitude of unstudied sills, e.g. near the western shore of Borgarfjörður eystri, by the cliffs east of Mosdalur, in Kerlingardalur, south of Herjólfsvík, by Náttmálafjall and north of Norðdalshnjúkur (Fig. 12e).

Other sub-volcanic intrusions of the area are the dome-shaped, rhyolitic Njarðvík sub-volcanic complex (Fig. 5; Burchardt, 2008; Gustafsson, 1992), as well as rhyolitic intrusions at the coast near Höfn in Borgarfjörður eystri.

25 Generally, rhyolitic intrusions appear to be more frequent in the N of BEL (Fig. 11)

Sub-volcanic vent structures frequently occur higher up in the stratigraphy of the volcanic structures in our study area. Gustafsson (1992) described some of the vents in the Njarðvík-Dyrfjöll area, for example the rhyolitic vent structures associated with the ring dykes on the peaks surrounding Njarðvík, the vent associated with the Dyrfjöll caldera, and the agglomerates of the vent producing the dacitic Kambur lava (see Fig. 4 for locations). In the Breiðuvík caldera, several

30 basaltic vents cut through the Hvítserkur ignimbrite and the overlying lake sediments and are in some cases connected to the hyaloclastites and pillow breccias at the summit of Hvítserkur (Fig. 8). In the southern part of the study area (see 
Fig. 9 for locations), a basaltic vent with red scoria deposits forms the summit of Náttmálafjall and a dacitic vent is connected to the dacite lava near the summit of Skúmhattadalsbrik (Fig. 10b; M. Lapp, 1990a). Moreover, the vent to the Priggjahnjúkafjall rhyolite II lava is exposed in the mountain with the same name (M. Lapp, 1990a). 

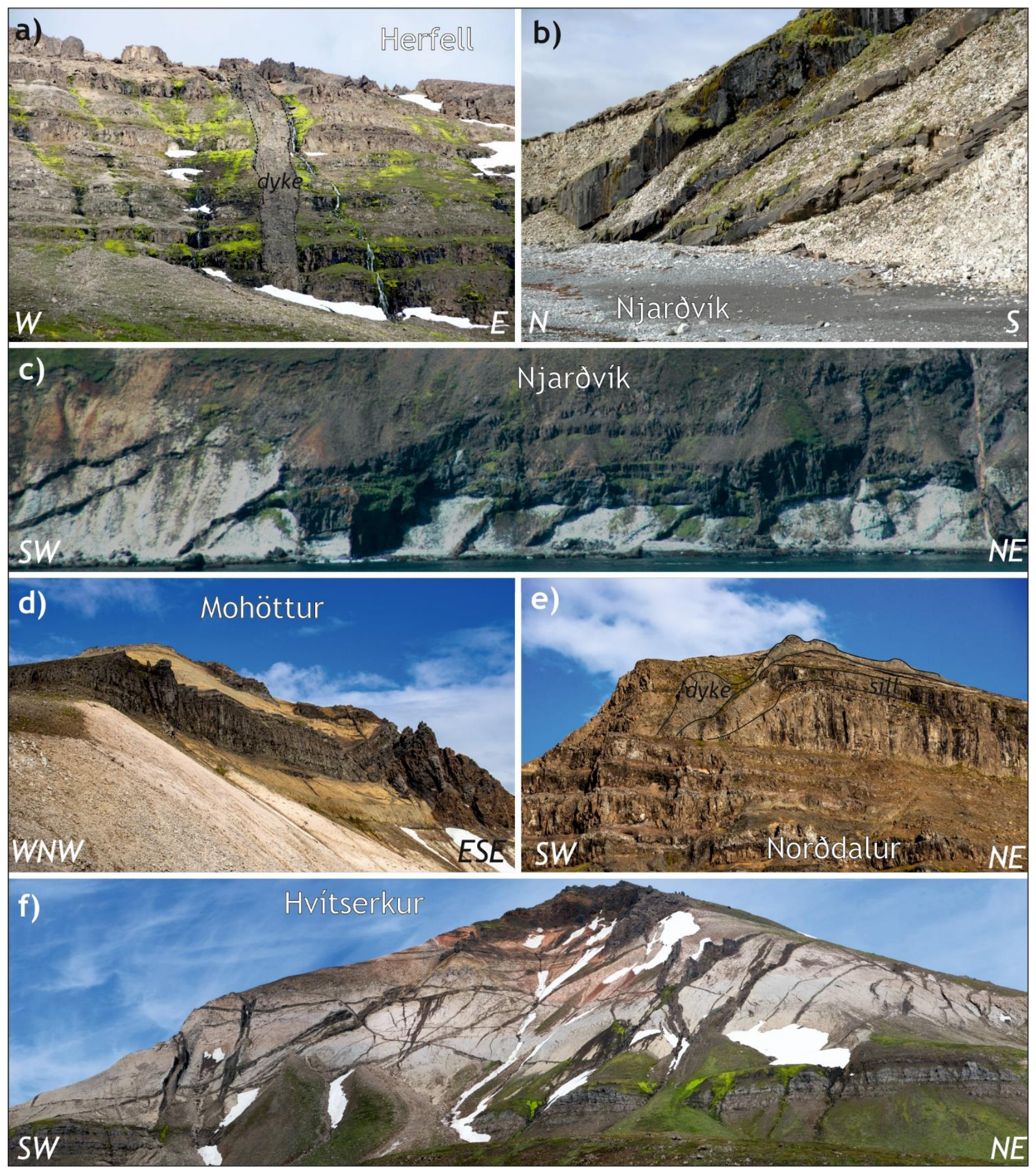

Figure 12. Annotated field photographs of magmatic intrusions in BEL. a) Regional dyke crosscutting basaltic lavas and rhyolitic ignimbrites on the south flank of Herfell. Thickness of the dyke is approximately $5 \mathrm{~m}$. b) Basaltic inclined sheets crosscutting the 
white subvolcanic rhyolite of the Njarðvík intrusive complex at the shore of Njarðvík. Middle sheet is about $0.5 \mathrm{~m}$ thick. c) The Njarðvík sill fed by inclined sheets crosscutting the white subvolcanic rhyolite of the Njarðvík intrusive complex at the shore of Njarðvík. See Burchardt (2008) for details. d) Basaltic sills, dykes and vent in the yellow-brown lake sediments of the Breiðuvík caldera. See Section 4.5.3 for a detailed description of the caldera and Burchardt et al. (subm.) for details on the intrusions. e)

5 Dyke and sill in the basaltic lavas on the northern end of Norðdalur. $f$ ) Basaltic dykes cutting the Hvítserkur ignimbrite of the Breiðuvík caldera. See Section 4.5.3 for a detailed description of the caldera and Burchardt et al. (subm.) for details on the intrusions.

\subsection{Collapse calderas and eruptive vents of ignimbrites}

The study area hosts a number of rhyolitic ignimbrites, some of them associated with collapse calderas and some

10 apparently originating from vents. In this section, we describe their occurrence and eruption features. Their comparative size and distribution are discussed. Most of the ignimbrites are located in the upper half of the exposed stratigraphy, underlain and overlain by olivine basalt lavas. One of the oldest ignimbrites in the stratigraphy from Húsavík was dated by Martin \& Sigmarsson (2010) at $13.10 \pm 0.20 \mathrm{Ma}$. Some, so far undated, ignimbrites occur in the lake sediments of the Breiðuvík caldera (see description below), the Kækjuskörð area, namely Orustukambur I and II,

15 as well as in Kerlingardalur and in Tóarhnjúkur.

\subsubsection{Njarðvík collapse calderas}

In the northern part of the study area, the cove of Njarðvík contains evidence for successive caldera collapse in two, partly overlapping calderas. The older of the two is evident from the concentric inward tilt of the basaltic lavas (Figs. 5e and 13 A-A'), forming a depression or downsag caldera with a centre close to the back of the valley (Fig. 4). No

20 eruptive deposits are associated with this caldera structure, and crosscutting relationships with the local intrusions indicates that it predates the Njarðvík silicic complex.

Renewed caldera formation occurred in connection to a rhyolitic ring dyke that extended from the sub-volcanic silicic intrusion in the bay upwards into the mountains surrounding Njarðvík and fed rhyolitic lava flows and pyroclastic rocks (Figs. 5a, c, d, e). Four of these eruption sites are exposed at the peaks of the mountains around Njarðvík and 25 exhibit remarkable exposures of rhyolitic feeder dykes, agglomerates, pyroclastics, and lava flows (Fig. 5a, c, d, e). The rhyolitic Náttmálahnúkur ignimbrite in southern Njarðvík may be associated with this caldera collapse. It contains petrified wood, has a maximum thickness of $150 \mathrm{~m}$ and formed at $12.61 \pm 0.16 \mathrm{Ma}$ (Berg et al., 2015) (Fig. 5f). Postdeposition tilting of up to $30^{\circ}$ towards the centre of the caldera may either indicate that the ignimbrite is unrelated to the second Njarðvík caldera, or that subsidence occurred subsequent to the eruption.

\subsubsection{Dyrfjöll collapse caldera}

Approximately $5 \mathrm{~km} \mathrm{SSW}$ of Njarðvík, an ignimbrite-forming eruption produced the roughly circular Dyrfjöll collapse caldera with a maximum diameter of 4 km (Figs. 4 and 6). The Dyrfjöll caldera is for the most part bound by steeply 
inward-dipping, well-exposed ring faults (Figs. 6 and 13 B-B'). While the bottom of the caldera is not exposed, an agglomerate-filled vent with welded ignimbrite is exposed at the northern caldera margin. The caldera is filled by at least $30 \mathrm{~m}$ of pink to green ignimbrite that is welded at its base and overlain by up to $3.5 \mathrm{~m}$ of air-fall deposits (Fig. 6f). Berg (2016) dated the Dyrfjöll ignimbrite at $12.40 \pm 0.19$ Ma.

\section{$5 \quad$ 4.5.3 Breiðuvík collapse caldera}

In the Breiðuvík area, parts of the mountains Hvítserkur, Hákarlshaus, and Leirfjall consist of the so-called Hvítserkur ignimbrite that is the infill of a ca. $7.5 \times 4.5 \mathrm{~km}$ collapse caldera (Figs. 7, 8, and 13 C-C') with an age of $12.50 \pm 0.60$ Ma (Martin and Sigmarsson, 2010) or $12.41 \pm 0.28 \mathrm{Ma}$ (Berg, 2016a). At the southern caldera rim, the flat-lying lavas of the caldera floor abruptly change dip to $55^{\circ}$ to the $\mathrm{N}$ at Herjólfsvíkurvarp. This abrupt change of dip of the lavas

10 towards the caldera is also observed in Náttmálafjall south of Hvítserkur and in Grenmor at the northern shore of Breiðuvík, where basaltic and rhyolitic lavas dip with up to $25^{\circ}$ to the SW (Vogler, 2014). To the northwest, the extent of the caldera is obscured by erosion within altered rhyolitic lavas.

The caldera floor is bowl-shaped with decreasing dips towards the caldera interior and filled by the Hvítserkur ignimbrite. The ignimbrite reaches a current exposed thickness of $180 \mathrm{~m}$ at the southern flank of Hvítserkur, $277 \mathrm{~m}$ on

15 its western flank, and $410 \mathrm{~m}$ on its northern flank. The ignimbrite itself is mostly unwelded and beige, topped by a 2-3 m thick, flat-lying pink airfall deposit on the south side of Hvítserkur. On the north side of Hvítserkur, Leirfjall, and in Hákarlshaus, the ignimbrite is locally welded and dark brown in colour. Petrified wood and plant remains have been found in the ignimbrite (Vogler, 2014). Although the caldera-filling ignimbrite is eroded in the northern part of the caldera in Breiðuvík, we could use the dip of the caldera-floor lavas and the top contact of the ignimbrite to reconstruct

20 the three-dimensional shape of the caldera (Fig. 14). Assuming that the caldera depression was filled by the ignimbrite as seen in the south, the total volume of the ignimbrite before erosion may have been around $4.07 \mathrm{~km}^{3}$. 


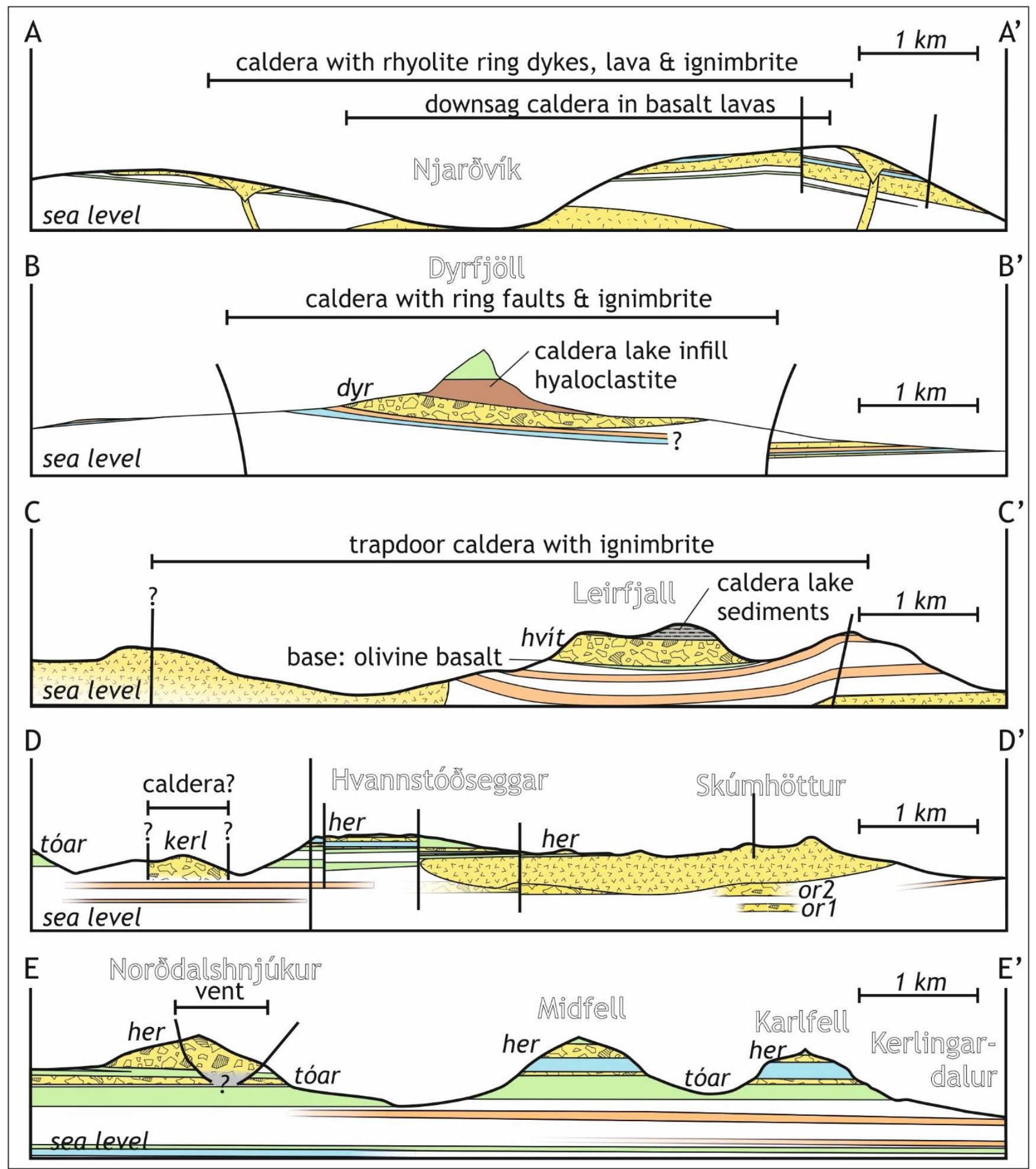

Figure 13. Cross sections through the collapse calderas and volcanic features associated with rhyolitic ignimbrites in the BEL area. 
For locations of cross sections and legend, see Figures 4, 7, and 9. Stratigraphic abbreviations from stratigraphic oldest to youngest: or $1=$ Orustukambur ignimbrite 1 , or $2=$ Orustukambur ignimbrite 2, kerl $=$ Kerlingardalur ignimbrite, tóar = Tóarhnjukur ignimbrite, $h e r=$ Herfell ignimbrite, $h v i t=$ Hvítserkur ignimbrite, dyr $=$ Dyrfjöll ignimbrite. $h e r$, hvít , and $d y r$ have approximetale the same age (ca. 12.4 Ma; Berg, 2016), the other ignimbrites are not dated.

5 Unusually high oxygen isotope values in the Hvítserkur and Dyrfjöll ignimbrites have been interpreted to result from prolonged hydrothermal alteration in the caldera lakes (Berg et al., 2018). The ignimbrite is overlain by a succession of lake sediments that range in thickness from less than $2 \mathrm{~m}$ in Hvítserkur to up to $70 \mathrm{~m}$ in Leirfjall. At their base, the lake sediments comprise interbedded sandstones and siltstones with reworked pumice and basalt grains. Cross-bedding and ripple marks in some of the beds indicate a shallow lake depth and water movement. The overlying mudstones to

10 sandstones contain pumice and desiccation cracks in several of the beds, which indicates that the sediment was likely sourced from the erosion of the Hvitserkur ignimbrite beyond the caldera and that the lake dried out episodically. Upsequence, the sandstones contain reworked pumice and basaltic grains. Towards the top, the sequence contains an up to $5 \mathrm{~m}$ thick distal ignimbrite with fiamme. This ignimbrite is overlain by a succession of brown to black, partly silicified mud- and siltstones. Numerous dykes and some sills crosscut the ignimbrite and the lake sediments, most of them are

15 composed of olivine basalt (see also Section 4.3). In Leirfjall, shallow intrusions with pepperites and a large vent indicate magma-water interaction at very shallow depths. In Hvítserkur, some dykes are connected to conduits feeding the pillow lavas and hyaloclastite at the summit. The occurrence of pillow lavas and hyaloclastite demonstrates that the Hvítserkur caldera lake still existed at the time of their eruption. However, the subaerial olivine basalt lava at the very summit of Hvítserkur testifies either to the end of the caldera lake or that phreatomagmatic volcanism changed to

20 effusive volcanism as the eruption reached above the level of the lake.

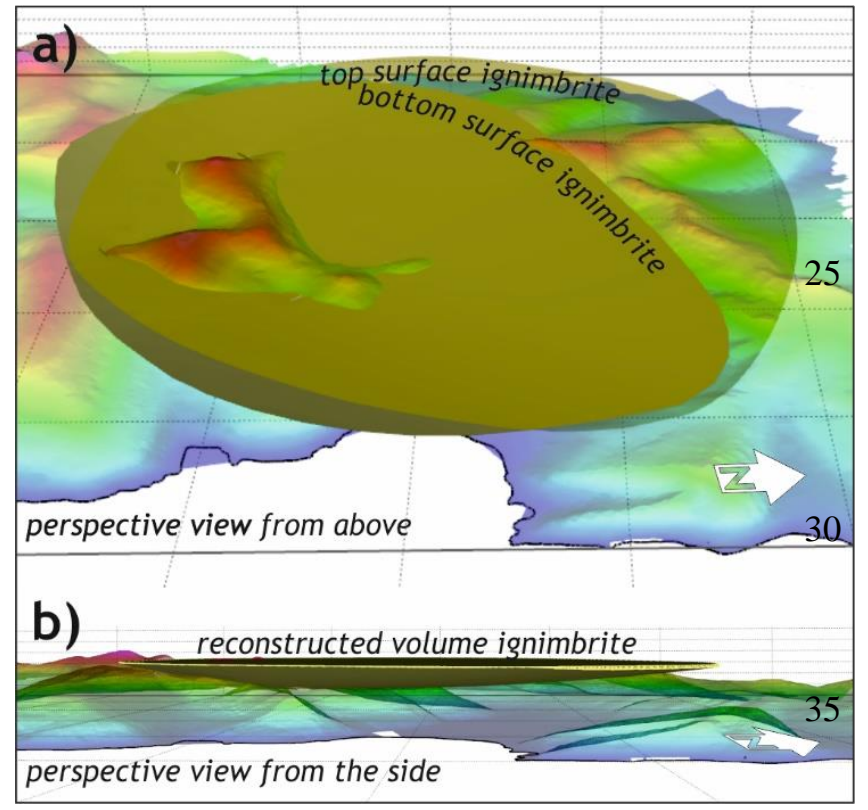

Figure 14. Three-dimensional reconstruction of the Breiðuvík caldera-infill (Hvítserkur) ignimbrite from mapping of the bottom and top surface of the ignimbrite. The reconstruction and volume calculation was done in Move 2018 (Petroleum Experts). The caldera bottom is bowl-shaped (see also Cross section $\mathrm{C}^{-\mathrm{C}^{6}}$ in Fig. 13). Note that the caldera depression was not entirely filled by the ignimbrite. A caldera lake existed after eruption, as evident from lacustrine sediments and basaltic hyaloclastites erupted in the lake. 
The southern part of our study area (Loðmundarfjörður) contains several rhyolitic ignimbrite sheets throughout the stratigraphic sequence (Figs. 9 and 13 D-D' and E-E'). Moreover, ignimbrites are locally exposed in numerous locations around the study area, where they can often not be linked to any of the identified collapse calderas. In

5 general, we use the size of lithics and the degree of welding to identify proximity to the source locations of ignimbrites.

From bottom to top, the following ignimbrite sheets have been identified: Orustukambur I (ca. 200-230 m a.s.l.) and II (ca. 300-380 m a.s.1.), Tóarhnjúkur (ca. $700 \mathrm{~m}$ a.s.1.), and Herfell (ca. 900-1020 m a.s.1.). These ignimbrites can be traced south to Seyðisfjörður and west to Fljótsdalur (Óskarsson and Riishuus, 2019). The Orustukambur II ignimbrite

10 has been suggested to originate from Skumhöttur (Thomas, 1988) where there is evidence for an eruptive centre. Alternatively, the Orustukambur II ignimbrite may originate from the ignimbrite outcrop in nearby Kerlingardalur (Fig. 9), which we interpret as a possible caldera infill ignimbrite, mainly based on the proximal nature of the ignimbrite. We suggest that the Tóarhnjúkur ignimbrite sheet originates from somewhere close to the mountain with that name west of Loðmundarfjörður (Fig. 9). Regarding the source of the Herfell ignimbrite, Gustafsson et al. (1989)

15 used thickness isopachs to suggest a source west of Miðfell. Our mapping of this area identified a funnel-shaped vent in Norðdalshnjúkur (Figs. 10d and 13 E-E'). The vent exposure is about $200 \mathrm{~m}$ deep and contains several, inwarddipping rhyolite flows with tuff breccia holding angular fragments of basalt at the base and grading into rhyolitic ignimbrite upwards. On the NE side of Norðdalshnjúkur, a rhyolitic dyke cuts the underlying basalt and connects to the rhyolite lavas in the caldera. The ignimbrite is the same as the one covering the mountain Herfell (Herfell ignimbrite),

20 which is welded in western Herfell and unwelded further east, where its thickness decreases from $120 \mathrm{~m}$ in Herfell to $60 \mathrm{~m}$ in Skælingur. The Herfell ignimbrite has been dated by Berg, (2016) to $12.40 \pm 0.12 \mathrm{Ma}$.

In summary, our observations of the distribution of rhyolitic ignimbrites and collapse calderas shows various styles of collapse caldera structures (cf. Lipman), such as a downsag caldera (Njarðvík, older caldera), a caldera bound by ring dykes (Njarðvík, younger caldera), a piston caldera (Dyrfjöll), and a trapdoor caldera (Breiðuvík). These calderas

25 range in size from ca. $4.5 \mathrm{~km}$ (Dyrfjöll) to ca. $7.5 \mathrm{~km}$ (Breiðuvík) in diameter and were up to ca. $450 \mathrm{~m}$ deep (Breiðuvík).

\section{DISCUSSION AND CONCLUSIONS}

\subsection{Summary of the observations and general volcanostratigraphy}

30 The Borgarfjörður eystri and Loðmundarfjörður area north of Seydisfjörður and on the eastern flank of Héraðsflói consist of an area of Neogene silicic volcanism characterised by a wealth of volcanic and sub-volcanic structures and 
extraordinary natural beauty. Here, we summarise the general observations we and previous workers made to come to some conclusions on the geological history of the area.

Generally, the rocks in our study area belong to a phase of silicic, central-type volcanism that is bracketed by regional flood basalts, both at the base and the top. Below the basal flood basalts, silicic volcanic rocks that occur at low 5 elevations among the rocks at the east coast (e.g., around Húsavík) testify to the existence of still older, now-eroded volcanoes to the east. Their deposits are overlain by flat-lying basaltic lavas, intercalated with a few marker horizons, such as at least two extensive icelandite lavas, in the lower part of the stratigraphic sequence. The Jónsfjall olivine basalts, the Hvannstóðsdalur porphyritic basalts and the icelandites, had centers of accumulation south of midBorgarfjörður, near Hvannstóðsdalur (cf. Fig. 2; see Fig. 3 for locations). Outside of these, the topography was flat at

10 the onset of central-type volcanism.

Mapping of the regional olivine basalt groups and intrusive and extrusive rocks of the central volcanoes and dating of the rocks in the study area show that the volcanic centres described above developed simultaneously and in a common way. Early tholeiitic volcanism in central volcanoes formed fields around their respective dyke swarms. These were partly covered by olivine flood basalts of Jónsfjall group, that accumulated in the Loðmundarfjörður area. At the same

15 time, voluminous rhyolitic magmatism occurred in the entire area, comprising sub-volcanic intrusions at depth, and rhyolitic lava flows and lava dome eruptions at the surface. Several near-contemporaneous caldera-forming ignimbrite eruptions occurred in Njarðvík, Dyrfjöll, Breiðuvík, and probably other locations and marked the violent culmination of silicic volcanism (cf. Berg, 2016). Lake sediments in the Breiðuvík caldera document erosion of the Hvítserkur ignimbrite deposited outside the caldera, but also catches distal deposits of another silicic ignimbrite. Olivine basalt

20 volcanism then became dominant, intruding the caldera-infill ignimbrites and lake sediments, erupting within, and filling, the caldera lakes and finally covering the volcanic landscape. Towards the very end of the silicic magmatism voluminous olivine basalts of the Hólmar group erupted during large regional fissure eruptions extending far south of the study area, the remains of which are found on the mountain peaks of Loðmundarfjörður.

\subsection{Central volcanoes or a volcanic cluster?}

25 Previously, the volcanic structures in the BEL area have been sub-divided into several central volcanoes (Gustafsson et al., 1989). This subdivision was based on the spatial distribution of caldera structures, vents, and silicic rocks, as well as topographic features, such as fjords. Moreover, Gustafsson et al. (1989) applied the concept of volcanic systems with a discrete central volcano as the site of silicic magma eruption, as observed in the present-day rift zone. However, Burchardt et al. (2011) proposed that the volcanic centres were in fact overlapping in space and time, based on the 30 arrangement of intrusive sheet swarms in Njarðvík and Borgarfjörður eystri. Indeed, subsequent radiogenic dating of silicic rocks across the entire study area by (Berg, 2016) demonstrated that extrusive units and collapse calderas 
formed roughly contemporaneously. Our compiled maps, including the volcano-stratigraphy summarised above (Section 5.1), confirm this picture of wide-spread silicic volcanism with multiple and dispersed eruption sites forming a large volcanic cluster.

In fact, the varied flow directions of the rhyolite lavas indicate that there was no central summit. Instead, the relief of

5 individual rhyolite flows formed temporary elevation highs that were often subsequently straightened out and covered by basaltic and intermediate lava flows. Collapse calderas formed both within areas with a high density of rhyolitic vents, such as Njarðvík and Breiðuvík, and at the edges of the rhyolitic areas, such as in Dyrfjöll, Herfell, and Thóarhnjukur. The calderas exhibit a variety of collapse styles, ranging from downsag in Njarðvík to trapdoor in Breiðuvík to ring faulting in Dyrfjöll (Fig. 13). The near-contemporaneous formation of four voluminous ignimbrites

10 in the area, the largest of them without clear associated caldera depression, and their similar composition may indicate that there was a common source.

\subsection{Implications for rift zone architecture during the Neogene}

To sum up, BEL magmatism is characterised by the following features that notably differ from the present-day rift zone activity:

15 - The dip of the lava pile deviates from the regional westward dip and is forming a much larger dip anomaly than any other one associated with eroded central volcanoes.

- The nature, volume and spatial extent of marker horizons, such as the porphyritic group lavas and the two icelandite flows, is unusual.

- The distribution of regional dykes is not indicating the existence of distinguishable, elongated dyke swarms.

- The overall volume of silicic rocks, as well as the volume of individual silicic units is unusual for Iceland.

- The distribution of silicic volcanism in numerous eruptive centres and several calderas is unlike current silicic volcanoes with more focussed activity.

These peculiarities let us wonder about the geodynamic setting of the BEL during the Neogene, in particular since the detailed arrangements of rift/volcanic zones in the past are still unclear, although a number of models exist that attempt

25 to explain the distribution of extinct volcanoes and the high crustal thickness (cf. Fig. 1a; e.g. Blischke, 2020; Helgason, 1984; Palmason, 1980; Smallwood et al., 1998; Walker, 1975). The composition of the rocks in the area is tholeiitic to mildly alkaline (Berg, 2016; Gustafsson, 1992), which may indicate that volcanism in the area occurred in a propagating rift zone, similar to the southern part of the recent Eastern Volcanic Zone (Jakobsson, 1972; Óskarsson et al., 1982). Alternatively, Martin et al. (2011) proposed that the area formed at the juncture of a Neogene oceanic

30 transform fault (equivalent to the recent Tjörnes Fracture Zone) and the Neogene rift zone. Yet a different scenario is that the volcanic cluster in the BEL area formed on the shoulder of the rift zone or in an off-rift setting. Generally, off- 
rift volcanism is assumed to lack signs of extension expressed as tectonic thinning through graben formation or magmatic extension in the form of eruptive fissure swarms at the surface and regional dyke swarms at depth (cf. Maccaferri et al., 2014).

Unfortunately, our current knowledge based on our mapping and observations so far cannot fully resolve the

5 uncertainty regarding these scenarios as yet. However, we note the absence of any structures indicating faulting in a transform zone. The remnants of such a transform might be found to the north at the seafloor. Regarding the off-rift or propagating rift setting, we note the occurrence of normal faulting and regional dykes indicating NNE-SSW extension. However, the BEL area lacks signs of focussed fissure swarms.

\subsection{Open questions and suggestions for future research}

10 We conclude our report on the geology of the BEL area with a number of suggestions for future research that are based on our current state of knowledge.

On the scale of Eastern Iceland as a whole, we highlight the need for a reconstruction of the geodynamic setting following the North Atlantic rift zone relocation from the Ægir Ridge to the Kolbeinsey Ridge after about 30 Ma. Systematic age dating of the extinct volcanic systems in Eastern Iceland and the Westfjords could provide the

15 currently missing puzzle piece to reconstruct the arrangements of rift zones in the past.

On the scale of the entire study area, we highlight the need for more detailed mapping and additional radiogenic dating and petrological work to unravel open questions, such as

(1) the nature, structure, and origin of the older silicic rocks underlying the volcanic sequence we describe here;

(2) the relationship between silicic and mafic magmatism, in particular the relationship between central type silicic and

20 regional olivine basalt magmatism;

(3) the origin and context of unstudied rhyolitic ignimbrites;

(4) a more detailed investigation of all ignimbrites in order to assess the relationship between contemporaneous ignimbrites to shed light on a potential common source;

(5) the detailed structure of the regional dyke swarms, including the distribution and density of dykes; and

25 (6) the stratigraphic connection of the study area with the areas to the south (Seyðisfjördur) and west (Héraðsflói and Vopnafjörður).

Moreover, on a smaller scale, we encourage further investigations of individual features such as (1) the stratigraphy of individual ignimbrites; (2) vent structures; (3) the structure of individual intrusions; (4) the structure of the different collapse calderas; (5) the nature, structure, and origin of the regionally extensive icelandite lavas.

30 Despite our combined more than 35 years of geological investigations into the Borgarfjörður eystri/Loðmundarfjörður area between Héraðsflói in the northwest and Seyðisfjördur in the south, we realise that we are just at the beginning of 
unravelling the geology of this northeastern part of Eastern Iceland, which certainly has the potential for new and exciting research. We would therefore like to invite the scientific community to use this publication as a stepping stone for their own research in the area.

\section{AUTHOR CONTRIBUTIONS}

SB initiated the effort to write up a summary of the known geology of the BEL area. The bulk of the content was created during LEG's PhD mapping of the area and his supervision of B. Lapp, M. Lapp, and L. Thomas during the 1980s and 1990s, as well as various field campaigns by SB for her own PhD, supervision of SEB, and other campaigns, and several mapping campaigns by BVO for the Icelandic Institute of Natural History. MSR supervised

10 SEB during her PhD. SEB did fieldwork, sampling, and analysis. SB, BVO, and LEG wrote the manuscript, and SB and BVO created the figures. All authors commented on the manuscript.

\section{ACKNOWLEDGEMENTS}

This study is the summary of more than 35 years of field work in the BEL area, partly related to the authors' $\mathrm{PhD}$

15 theses, partly to systematic mapping by the Icelandic Institute of Natural History, and partly as a homage to the beauty of this area. Geological investigations in the area were furthermore supported by funding from the Royal Swedish Academy of Sciences, the Swedish Research Council, and the Knut and Alice Wallenberg Foundation to SB, a PhD stipend from Nordvulk, a Liljewalch stipend and research funding from Uppsala University to SEB.

The authors are grateful for field assistance by the late Helgi Arngrímsson, Lutz Thomas, Bernhard Lapp, Manuel

20 Lapp, Michael Krumbholz, Valentin Troll, Einar Bessi Gestsson, Elodie Saubin, Jonathan Davidson, Ben Kennedy, Hugh Tuffen, Andrea, Christian Weltch, Alex Voos, and Vinícius Moraes.

\section{DATA AVAILABILITY}

The Geological map in Fig. 3 will be inlcuded in the updated geological map of Northeast Iceland by the Icelandic

25 Institute of Natural History.

\section{REFERENCES}

Berg, S. E. (2016). Silicic Magma Genesis in Basalt-dominated Oceanic Settings Examples from Iceland and the Canary Islands [Uppsala University]. http://urn.kb.se/resolve?urn=urn:nbn:se:uu:diva-272318

30 Berg, S. E., Troll, V. R., \& Burchardt, S. (2014a). Making Earth's earliest continental crust - an analogue from voluminous Neogene silicic volcanism in NE-Iceland. Geophysical Research Abstracts, EGU2014-13953.

Berg, S. E., Troll, V. R., Burchardt, S., Riishuus, M. S., Krumbholz, M., \& Gústafsson, L. E. (2014b). Iceland's best kept 
secret. Geology Today, 30(2), 54-60. https://doi.org/10.1111/gto.12042

Berg, S. E., Troll, V. R., Harris, C., Deegan, F. M., Riishuus, M. S., Burchardt, S., \& Krumbholz, M. (2018). Exceptionally high whole-rock $\delta 18 \mathrm{O}$ values in intra-caldera rhyolites from Northeast Iceland. Mineralogical Magazine, 82(5), 1147-1168. https://doi.org/10.1180/mgm.2018.114

5 Blischke, A. (2020). The Jan Mayen microcontinent and Iceland Plateau: Tectono-magmatic evolution and rift propagation [University of Iceland]. https://opinvisindi.is/handle/20.500.11815/1826

Burchardt, S., \& Gudmundsson, A. (2009). The infrastructure of the Geitafell Volcano, Southeast Iceland. In: Thordarson, T., Self, S., Larsen, G., Rowland, S., Hoskuldsson, A. (eds.). Studies in Volcanology: The Legacy of George Walker. Special Publications of IAVCEI 2. Geological Society, London, 349-370.

10 Burchardt, S. (2008). New insights into the mechanics of sill emplacement provided by field observations of the Njardvik Sill, Northeast Iceland. Journal of Volcanology and Geothermal Research, 173(3-4), 280-288. https://doi.org/10.1016/j.jvolgeores.2008.02.009

Burchardt, S., Tanner, D. C., Troll, V. R., \& Gustafsson, L. E. (2011). Three - dimensional geometry of concentric intrusive sheet swarms in the Geitafell and the Dyrfjöll volcanoes, eastern Iceland. 12(7), 1-21. https://doi.org/10.1029/2011GC003527

Carley, T.L., Miller, C. F., Wooden, J. L., Padilla, A. J., Schmitt, A. K., Economos, R. C., Bindeman, I. N., \& Jordan, B. T. (2014). Iceland is not a magmatic analog for the Hadean: Evidence from the zircon record. Earth and Planetary Science Letters, 405, 85-97.

Carley, Tamara L., Miller, C. F., Fisher, C. M., Hanchar, J. M., Vervoort, J. D., Schmitt, A. K., Economos, R. C., Jordan, B. T., Padilla, A. J., \& Banik, T. J. (2020). Petrogenesis of Silicic Magmas in Iceland through Space and Time: The Isotopic Record Preserved in Zircon and Whole Rocks. The Journal of Geology, 128(1), 1-28. https://doi.org/10.1086/706261

Carmichael, I. S. E. (1964). The petrology of Thingmuli, a tertiary volcano in Eastern Iceland. Journal of Petrology, 5(3), 435-460. https://doi.org/10.1093/petrology/5.3.435

25 Dearnley, R. (1954). A contribution to the geology of Lodmundarfjördur. Acta Nat. Islandica, 1(9), 1-29.

Foulger, G. R., Gernigon, L., \& Geoffroy, L. (2021). Icelandia. In G. R. Foulger, L. C. Hamilton, C. A. Jurdy, D. M., Stein, K. A. Howard, \& S. Stein (Eds.), In the Footsteps of Warren B. Hamilton:New Ideas in Earth Science (Vol. 553, Issue 04, pp. 1-12). https://doi.org/10.1130/2021.2553(04

Fridleifsson, G. O. (1983). Geology and Alteration History of the Geitafell Central Volcano, Southeast Iceland. [University of Edinburgh.]

Furman, T., Meyer, P. S., \& Frey, F. (1992). Evolution of Icelandic central volcanoes: evidence from the Austurhon intrusion, southeast Iceland. Bulletin of Volcanology, 55, 45-62.

Gibson, I. L. (1963). The Reydarfjordur Acid Volcanic Centre. [University of London.]

Gustafsson, L. E. (1992). Geology and Petrography of the Dyrfjöll Central Volcano, Eastern Iceland. [Freie Universität 39 
Berlin.]

Gustafsson, L. E., Lapp, B., Thomas, L., \& Lapp, M. (1989). Tertiary silicic rocks in the area of the Kaekjuskörd rhyolitic volcano, Eastern Iceland. Jökull, 39, 75-89.

Helgason, J. (1984). Frequent shifts of the volcanic zone in Iceland. Geology, 12, 212-216.

5 Hjartason, Á., Erlendsson, Ö., \& Blischke, A. (2017). The Greenland - Iceland - Faroe Ridge Complex. In G. PérnonPindivic, J. R. Hopper, M. S. Stoker, C. Gaina, J. C. Doornebal, T. Funck, \& U. E. Árting (Eds.), The NE Atlantic Region: A Reappraisal of Crustal Structure, Tectonostratigraphy and Magmatic Evolution (pp. 127-148). Geological Society, London, Special Publication. https://doi.org/https://doi.org/10.1144/SP447.14

Jakobsson, S. P. (1972). Chemistry and distribution pattern of recent basaltic rocks in Iceland. Lithos, 5(4), 365-386. https://doi.org/10.1016/0024-4937(72)90090-4

Jerram, D. A., \& Widdowson, M. (2005). The anatomy of Continental Flood Basalt Provinces: Geological constraints on the processes and products of flood volcanism. Lithos, 79(3-4 SPEC. ISS.), 385-405. https://doi.org/10.1016/j.lithos.2004.09.009

Klausen, M. B. (2004). Geometry and mode of emplacement of the Thverartindur cone sheet swarm, SE Iceland. Journal of Volcanology and Geothermal Research, 138(3-4), 185-204. https://doi.org/10.1016/j.jvolgeores.2004.05.022

Klausen, M. B. (2006). Geometry and mode of emplacement of dike swarms around the Birnudalstindur igneous centre, SE Iceland. Journal of Volcanology and Geothermal Research, 151(4), 340-356. https://doi.org/10.1016/j.jvolgeores.2005.09.006

Lapp, B. (1988). Geologische Kartierung am Lodmundarfjördur (Nordost-Island) unter besonderer Beruecksichtigung der Basalte. M.Sc. thesis Freie Universität Berlin.

Lapp, M. (1990). Geologische Kartierung am Lodmundarfjördur (Nordostisland) unter besonderer Beruecksichtigung der sauren Gesteine. M.Sc. thesis Georg-August Universität Göttingen.

Liotta, D., Brogi, A., Ruggieri, G., Rimondi, V., Zucchi, M., Helgadóttir, H. M., Montegrossi, G., \& Friðleifsson, G. Ó. (2020). Fracture analysis, hydrothermal mineralization and fluid pathways in the Neogene Geitafell central volcano: insights for the Krafla active geothermal system, Iceland. Journal of Volcanology and Geothermal Research, 391, 106502. https://doi.org/10.1016/j.jvolgeores.2018.11.023

Maccaferri, F., Rivalta, E., Keir, D., \& Acocella, V. (2014). Off-rift volcanism in rift zones determined by crustal unloading. Nature Geoscience, 7(4), 297-300. https://doi.org/10.1038/ngeo2110

Martin, E., Paquette, J. L., Bosse, V., Ruffet, G., Tiepolo, M., \& Sigmarsson, O. (2011). Geodynamics of rift-plume interaction in Iceland as constrained by new $40 \mathrm{Ar} / 39 \mathrm{Ar}$ and in situ $\mathrm{U}-\mathrm{Pb}$ zircon ages. Earth and Planetary Science Letters, 311(1-2), 28-38. https://doi.org/10.1016/j.eps1.2011.08.036

Martin, E., \& Sigmarsson, O. (2010). Thirteen million years of silicic magma production in Iceland: Links between petrogenesis and tectonic settings. Lithos, 116(1-2), 129-144. https://doi.org/10.1016/j.lithos.2010.01.005

Óskarsson, B. V., \& Riishuus, M. S. (2013). The mode of emplacement of Neogene flood basalts in Eastern Iceland: Facies 40 
architecture and structure of the Hólmar and Grjótá olivine basalt groups. Journal of Volcanology and Geothermal Research. https://doi.org/10.1016/j.jvolgeores.2013.09.010

Óskarsson, B. V, \& Riishuus, M. S. (2014). The mode of emplacement of Neogene flood basalts in eastern Iceland: Facies architecture and structure of simple aphyric basalt groups. Journal of Volcanology and Geothermal Research, 289, 170-192.

Óskarsson, B. V. and Riishuus, M. S. (2019). Geological map of Eastern Iceland. 1:100 000, Garðabær: Icelandic Institute of Natural History, 1st edition, ISBN 978-9935-9285-1-1.

Óskarsson, B. V., Andersen, C., \& Riishuus, M. S. (2017). The mode of emplacement of Neogene flood basalts in Eastern Iceland: The plagioclase ultraphyric basalts in the Grænavatn group. Journal of Volcanology and Geothermal Research, 332, 26-50.

Óskarsson, N., Sigvaldason, G. E., \& Steinthórsson, S. (1982). A dynamic model of rift zone petrogenesis and the regional petrology of Iceland. Journal of Petrology, 23(1), 28-74. https://doi.org/10.1093/petrology/23.1.28

Oskarsson, N., Steinthorsson, S., \& Sigvaldason, G. E. (1985). Iceland geochemical anomaly: origin, volcanotectonics, chemical fractionation and isotope evolution of the crust. Journal of Geophysical Research, 90(B12), 11-21. https://doi.org/10.1029/jb090ib12p10011

Palmason, G. (1980). A continuum model of crustal generation in Iceland - kinematic aspects. Journal of Geophysics, 47(1), 7-18. https://journal.geophysicsjournal.com/JofG/article/view/69

Paquette, J., Sigmarsson, O., \& Tiepolo, M. (2007). Mesozoic zircons in Miocene ignimbrite from E-Iceland: a splinter of a continental crust? 9.

20 Saemundsson, K., (1979). Outline of the geology of Iceland. Jokull, 29, 7-28. https://ci.nii.ac.jp/naid/10003358236

Saubin, E., Kennedy, B., Tuffen, H., Villeneuve, M., Davidson, J., \& Burchardt, S. (2019). Comparative field study of shallow rhyolite intrusions in Iceland: Emplacement mechanisms and impact on country rocks. Journal of Volcanology and Geothermal Research, 388, 106691. https://doi.org/10.1016/j.jvolgeores.2019.106691

Sigmarsson, O., Maclennan, J., \& Carpentier, M. (2008). Geochemistry of Igneous Rocks in Iceland : a review. 58, 1-21.

25 Sigmundsson, F. (2006). Iceland Geodynamics. Crustal Deformation and Divergent Plate tectonics. Springer.

Smallwood, J. R., White, R. S., \& Staples, R. K. (1998). Deep crustal reflectors under Reydarfjördur, eastern Iceland: crustal accretion above the Iceland mantle plume.

Steinberger, B., Bredow, E., Lebedev, S., Schaeffer, A., \& Torsvik, T. H. (2019). Widespread volcanism in the GreenlandNorth Atlantic region explained by the Iceland plume. Nature Geoscience, 12(1), 61-68. https://doi.org/10.1038/s41561-018-0251-0

Thomas, L. (1988). Geologische Kartierung am Lodmundarfjördur (Nordost-Island) unter besonderer Beruecksichtigung der pyroklastischen Gesteine. M.Sc. thesis Freie Universität Berlin.

Thordarson, T., \& Larsen, G. (2007). Volcanism in Iceland in historical time: Volcano types, eruption styles and eruptive history. Journal of Geodynamics, 43(1), 118-152. https://doi.org/10.1016/j.jog.2006.09.005 
Thordarson, T., \& Self, S. (1993). The Laki (Skaftár Fires) and Grímsvötn eruptions in 1783-1785. Bulletin of Volcanology, 55(4), 233-263. https://doi.org/10.1007/BF00624353

Thoroddsen, T. (1901). Geological Map of Iceland. Landsbókasafn Íslands - Háskólabókasafn. https://islandskort.is/is/map/show/607;jsessionid=524A7DB463491F024AAA1275FC8FE2FB

5 Torsvik, T. H., Amundsen, H. E. F., Trønnes, R. G., Doubrovine, P. V., Gaina, C., Kusznir, N. J., Steinberger, B., Corfu, F., Ashwal, L. D., Griffin, W. L., Werner, S. C., \& Jamtveit, B. (2015). Continental crust beneath southeast Iceland. Proceedings of the National Academy of Sciences of the United States of America, 112(15), E1818-E1827. https://doi.org/10.1073/pnas.1423099112

Torsvik, T. H., Mosar, J., \& Eide, E. A. (2001). Cretaceous-Tertiary geodynamics: A North Atlantic exercise. Geophysical Journal International, 146(3), 850-866. https://doi.org/10.1046/j.0956-540X.2001.01511.x

Vogler, E. D. (2014). Berggrunnskortlagning Breiðuvíkur á Austfjörðum. University of Iceland.

Walker, G. P. L. (1966). Acid volcanic rocks in Iceland. Bulletin Volcanologique, 29(1), 375-402. https://doi.org/10.1007/BF02597164

Walker, G. P. L. (1971). Compound and simple lava flows and flood basalts. Bulletin Volcanologique, 35(3), 579-590. https://doi.org/10.1007/BF02596829

Walker, G. P. L. (1974). The Structure of Eastern Iceland. In Geodynamics of Iceland and the North Atlantic Area (pp. 177188). Springer Netherlands. https://doi.org/10.1007/978-94-010-2271-2_12

Walker, G. P. L. (1958). Geology of the Reydarfjördur area, Eastern Iceland. Quarterly Journal of the Geological Society of London, 114(1-4), 367-391. https://doi.org/10.1144/gsjgs.114.1.0367

20 Walker, G. P. L. (1964). Geological investigations in eastern Iceland. Bulletin Volcanologique, 27(1), 351-363. https://doi.org/10.1007/BF02597532

Walker, G. P. L. (1975). Excess spreading axes and spreading rate in Iceland. Nature, 255(5508), $468-471$. https://doi.org/10.1038/255468a0

Walker, G. P. L. (1963). The Breiddalur central volcano, eastern Iceland. Quarterly Journal of the Geological Society of London, 119(1-4), 29-63. https://doi.org/10.1144/gsjgs.119.1.0029 